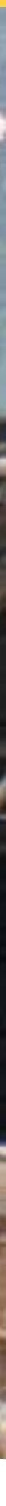

REDD+ politics in the media

A case study from Vietnam

Pham Thu Thuy

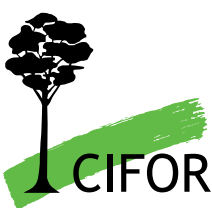



Working Paper 53

\title{
REDD+ politics in the media \\ A case study from Vietnam
}

\author{
Pham Thu Thuy
}


Working Paper 53

(c) 2011 Center for International Forestry Research

All rights reserved

Cover photo by Pham Thu Thuy

Pham, T.T. 2011 REDD+ politics in the media: a case study from Vietnam. Working Paper 53. CIFOR,

Bogor, Indonesia

CIFOR

Jl. CIFOR, Situ Gede

Bogor Barat 16115

Indonesia

T $+62(251) 8622-622$

F +62 (251) 8622-100

Ecifor@cgiar.org

\section{www.cifor.cgiar.org}

Any views expressed in this publication are those of the authors. They do not necessarily represent the views of CIFOR, the authors' institutions or the financial sponsors of this publication. 


\section{Table of contents}

Acknowledgements $\quad$ v

Abbreviations vi vii

Summary vii

Introduction $\quad 1$

1. Context and relevance of the study 2

1.1. Media analysis, climate change and REDD+ 2

1.2. The media in Vietnam 2

1.3. REDD+ in Vietnam 3

2. Methods $\quad \mathbf{4}$

2.1. Newspaper and article selection 4

2.2. Coding and media framing 5

$\begin{array}{ll}\text { 2.3. Key informant interviews } & 7\end{array}$

$\begin{array}{lr}\text { 2.4. 3Es framework } & 8\end{array}$

3. Results 9

3.1. Existing discourses and how they shape the national REDD+ arena 9

$\begin{array}{ll}\text { 3.2. Key actors controlling REDD+ discourse } & 18\end{array}$

$\begin{array}{lr}\text { 3.3. Future outlook for REDD+ } & 20\end{array}$

$\begin{array}{lr}\text { 3.4. 3Es assessment } & 23\end{array}$

4. Discussions and recommendations $\quad 27$

$\begin{array}{ll}\text { 4.1. REDD+ media coverage in Vietnam } & 27\end{array}$

4.2. The limits of the REDD+ media discourse in Vietnam 28

4.3. Who is to blame for the limited coverage of REDD+? 28

$\begin{array}{lr}\text { 4.4. Influence of the private sector } & 29\end{array}$

$\begin{array}{ll}\text { 4.5. Where are the poor? } & 30\end{array}$

$\begin{array}{lr}\text { 4.6. The way forward } & 30\end{array}$

Conclusions $\quad 32$

$\begin{array}{ll}\text { References } & 33\end{array}$ 


\section{List of figures and tables}

\section{Figures}

1. Frequency of articles 2005-2010 9

2. Policy events reported in the media which have influenced REDD in Vietnam 11

3. Level of debate in articles on REDD+ 12

4. Scale of REDD+ discussion 2005-2010 13

5. Percentage of articles associated with key REDD+ events 13

6. REDD+ placement in newspaper sections 16

\begin{tabular}{ll}
7. & Metatopics \\
\hline
\end{tabular}

8. Metatopics by year $\quad 17$

9. Metatopics by level $\quad 18$

10. Subtopics of politics and policy making 18

$\begin{array}{lr}\text { 11. Actors and metatopics } & 19\end{array}$

$\begin{array}{lr}\text { 12. Types of frames } & 20\end{array}$

$\begin{array}{lr}\text { 13. Outlook for REDD+ amongst commentators } & 21\end{array}$

14. Outlook for REDD+ over time $r 22$

15. Outlook for REDD+ by actor $\quad 22$

16. Assessment of the future of REDD+ and metatopics $\quad 22$

$\begin{array}{lr}\text { 17. } 3 \text { Es assessment } & 23\end{array}$

\begin{tabular}{lr} 
18. & 3 Es coverage over time \\
\hline
\end{tabular}

19. Actors and the 3Es $\quad 25$

20. Metatopics and the 3Es 25

\section{Tables}

1. Characteristics of newspapers selected 5

2. Results of key phrase search 6

3. Number of articles on REDD+ 6

4. Sources of information about REDD+ 15

5. Advocates and adversaries of REDD+ in Vietnam 19 


\section{Acknowledgements}

CIFOR, the Center for International Forestry Research, analyses policy, practice and implementation in its Global Comparative Study on REDD+, and disseminates lessons learned to a national and global audience. Our goal is to generate knowledge and practical tools to support efforts to reduce forest emissions in ways that are effective, efficient and equitable and that generate co-benefits such as poverty alleviation and biodiversity conservation. This study on 'REDD+ politics in the media' is part of the methodological framework for the Global Comparative Study's work on national REDD+ policies and processes. The framework was prepared by Maria Brockhaus, Monica Di Gregorio and Sheila Wertz-Kanounnikoff.

We are especially grateful to Jeffrey Broadbent, Clare Saunders, Stephan Price and other members of the Comparing Climate Change Policy Networks (COMPON) project for their development and application of a media discourse methodology on national responses to proposed global climate change regimes.

This report benefited from valuable comments from Monica Di Gregorio and Maria Brockhaus. Special thanks must also go to Nguyen Tuan Viet and Nguyen Duc Tu for their support in collecting the print copies of articles and their kind help in arranging and conducting all interviews. We also highly appreciate the support of interviewees who agreed to participate in this study.

We gratefully acknowledge the support received from the Norwegian Agency for Development Cooperation, the Australian Agency for International Development, the UK Department for International Development, the European Commission, the Department for International Development Cooperation of Finland, the David and Lucile Packard Foundation, the Program on Forests, the US Agency for International Development and the US Department of Agriculture's Forest Service. 


\section{Abbreviations}

$\begin{array}{ll}\text { CIFOR } & \text { Center for International Forestry Research } \\ \text { COP } & \text { Conference of the Parties } \\ \text { FAO } & \text { Food and Agriculture Organization of the United Nations } \\ \text { MARD } & \text { Ministry of Agriculture and Rural Development, Vietnam } \\ \text { NGO } & \text { Nongovernmental organisation } \\ \text { PES } & \text { Payment for environmental services } \\ \text { REDD+ } & \text { Reducing emissions from deforestation and forest degradation } \\ \text { UNDP } & \text { United Nations Development Programme } \\ \text { UNFCCC } & \text { United Nations Framework Convention on Climate Change } \\ \text { UN-REDD } & \text { United Nations Collaborative Programme on Reducing Emissions } \\ & \text { from Deforestation and Forest Degradation in Developing Countries } \\ \text { VFEJ } & \text { Vietnam Forum of Environmental Journalists } \\ \text { VND } & \text { Vietnamese dong }\end{array}$




\section{Summary}

The media can play a significant role in shaping public opinion on environmental policy and can influence the process of policy formulation and implementation. However, research exploring these impacts has been limited, particularly in developing countries and in the context of REDD+ (reducing emissions from deforestation and forest degradation). Using Vietnam as a case study, this report explores media coverage of REDD+ and discusses its impacts on REDD+ development and implementation in Vietnam. This study also identifies key actors discussing REDD+ and opportunities and constraints for reporting on REDD+ in Vietnam. Three representative newspapers were selected and articles from these were searched using key phrases related to REDD+ and then coded using media framing and a media code book. Nine in-depth interviews with journalists who have reported on REDD+ were also conducted to complement the interpretation of the data.

This study highlighted three factors that influence the media in reporting on REDD+ in Vietnam. First, the government is engaged in international REDD+ initiatives and various national policies on REDD+ have been developed. Secondly, the media is controlled by the government; the official role of media is to spread propaganda about state politics and policies and promote patriotism and socialist ideology. Thirdly, local stakeholders lack information and journalists have limited capacity.

Since the media in Vietnam is mainly a vehicle of the Party, the results of this media analysis should be interpreted differently from countries with a free press. This analysis thus reflects the positions of the Party rather than other actors.

The media in Vietnam has covered REDD+ issues since 2007 and has gradually increased its reporting thanks to the launch of numerous REDD+ policies and programmes. The fact that REDD+ coverage has improved in both quantity and quality shows that REDD+ has received increasing attention and support from the government and donors, and the opportunities for financial flows are recognised. However, REDD+ receives much less coverage than other climate change issues because:
- the major focus of concern about climate change in Vietnam is rising sea levels not REDD+;

- journalist have a limited understanding of REDD+; and

- scientists, the private sector and civil society organisations have limited voices in the policy making process and are not active participants in the debate.

As a result of the government's control of the media, coverage of REDD+ reflects government policy and orientation. Reporting on REDD+ is mainly framed around the implementation of the national REDD+ programme and policies, and associated issues related to effectiveness and equity. Efficiency issues have not been widely discussed since the priority of the government and donors was piloting the scheme and they covered these costs themselves.

This report identifies international organisations and government agencies as the key actors discussing REDD+ in Vietnam. While the perspectives of business enterprises were raised in the media coverage, the voices of scientists, international nongovernmental organisations (NGOs), civil society and marginalised groups were absent. The government, and international organisations are optimistic about the future of REDD+, particularly its effectiveness and equity impact, while business associations and some journalists expressed their concern about equity issues.

The media presents little analysis of the potential negative impacts of REDD+, including controversial and critical issues often raised by scientists and the international community such as leakage, insecure land tenure, involvement of indigenous groups and technical challenges such as carbon measurement. However, this study suggests that journalists should not be blamed for the limited coverage of REDD+ since the government, scientists, civil society and NGOs have a responsibility to ensure the public is given comprehensive and up-to-date information. Further training of journalists on REDD+ and better coordination and knowledge sharing amongst stakeholders are essential in facilitating REDD+ implementation in Vietnam and improving media coverage on REDD+. 



\section{Introduction}

Reducing emissions from deforestation and forest degradation $(\mathrm{REDD}+)^{1}$ has received increasing international and national attention. REDD+ primarily refers to i) developing mechanisms to make payments to developing countries for reducing emissions from deforestation and forest degradation (relative to a reference level); and ii) readiness activities that prepare countries for participation in the REDD+ mechanism (Angelsen 2008). While REDD+ is generally accepted to be important in global efforts to reduce emissions, little analysis has been made of how far policy makers and the general public understand REDD+ and what they expect from it. This creates difficulties for the national implementation of REDD+.

Mass media is often seen as an important means to shape the expression of political identities and culture (Dittmer, 2005) and influence public perceptions of an issue (Boykoff 2008). Conversely, the policy agenda also often directly influences the media agenda (Rogers and Dearing 2007). Yet, analysis and understanding of media coverage of climate change in general and REDD+ in particular are limited (Mansfield 2007, Fahn 2008). Several studies have attempted to address this gap but these analyses only look at climate change issues in general (Boykoff 2008, Dung 2008, Tynkkynen 2010). In-depth study is needed of media coverage of REDD+ to complement technical efforts in addressing REDD+ issues.

REDD+ offers the potential to channel significant financial resources to developing countries if they can show a measurable reduction in deforestation and forest degradation (CIFOR 2010a). The mechanism, however, is still new and requires 'learning by doing'.
To address this challenge, CIFOR is carrying out a global comparative study on REDD+. The project draws out lessons learned by identifying what works in REDD+ initiatives. At least nine countries in Latin America, Africa and Asia will be included in the study over the four years. This study is part of the national REDD+ policies and processes component of the Global Comparative Study on REDD+ (GCSREDD+) designed and coordinated by CIFOR. Using Vietnam as a case study, this study aims to address the following research questions:

- What are the existing discourses in the country's media and how do they shape the options negotiated in the national REDD+ arenas?

- Who are the key actors influencing or using specific discourse about REDD+ in the media?

- What are opportunities and constraints for journalists and reporters in Vietnam in covering REDD+?

Through analysis of media discourses this study intends to identify how REDD+ debates are framed in the policy domain, what concerns and claims are expressed in these, how different narratives about REDD+ relate to each other, and how these are used by actors representing different interests to strengthen political coalitions.

The report is structured in four parts: part 1 establishes the relevance of this study and provides an overview of REDD+ and the role of the media in Vietnam; part 2 presents the methodology used in compiling and coding media coverage of REDD+; part 3 presents the results of the study; and part 4 discusses the result of the analysis and offers recommendations.

1 Terminology around reducing emissions from deforestation is changing. Since the 2009 UN Climate Change Conference in Copenhagen we use the full abbreviation REDD+, which stands for reducing emissions from deforestation and forest degradation and enhancing forest carbon stocks in developing countries. Any references to RED or REDD refer to earlier agreements on the same mechanisms, more limited in scope (Angelsen 2009). 


\section{Context and relevance of the study}

\subsection{Media analysis, climate change and REDD+}

The mass media is a key actor in identifying and interpreting environmental issues and mediating a social relationship between scientists, policy actors and the public (Spector and Kitsuse 1977, Schoenfeld et al. 1979, Beck 1992, Baron 2006, Boykoff and Boykoff 2007, Carvalho 2007, Moser and Dilling 2007, Boykoff and Mansfield 2008). The media not only empowers people to make informed choices by reporting the news objectively (Shanahan 2007) but can also act as an important 'validator' of science (Carvalho 2007). Paletz (1999) and Crow (2010) also highlight the role of the media as a watchdog on government and as an effective public forum for people to express their opinions and exert certain influence on policy formulation and change.

With increased public interest in climate change in general and REDD+ in particular, scholars from a range of disciplines have focused their attention on media coverage of these issues (Wilson 1995, Boykoff and Boykoff 2007, Boykoff and Mansfield 2008, Anderson 2009). However, gaps in the literature call for further research. Boykoff and Boykoff (2007) pointed out that the influence of the media and environmental policy making on each other has not been widely studied. Crow (2010) further asserted that most media scholarship related to the policy cycle does not establish causality and no consistent and well-developed theory of media influence over policy processes has been established. Mass communication theories often overlook public policy processes and the public policy literature rarely analyses the role of media in the policy cycle in any depth (Crow 2010).

In addition, although the number of studies looking at the impact of media and climate change has increased, most focus on the US and UK press (Bendix and Liebler 1991, Boykoff and Boykoff 2007) and very few analyse these impacts in developing countries. More internationally comparative work which examines divergences across and within different media outlets that are governed by different socioeconomic, political and cultural contexts needs to be undertaken (Anderson 2009). Future research could fruitfully explore the reasons for different levels of coverage in different countries, their different emphases and why the views of developing countries are rarely aired (Painter 2007, Shanahan 2007, Anderson 2009). This would help to improve communication and identify the main barriers towards change (Anderson 2009, Crow 2010).

This study attempts to addresses these gaps by providing a case study exploring the roles of the media and policy entrepreneurs in initiating policy change in local environmental policy processes related to REDD+ in Vietnam.

\subsection{The media in Vietnam}

Political pressures significantly influence media characteristics (Carvalho 2007, Boykoff and Mansfield 2008). Those who control the media have the power to silence and suppress issues and decide what can be published (Anderson 2009). Although the media is recognised in the literature as a key actor in influencing policy formulation and implementation, often overlooked are the 'behindthe-scenes' battles which influence whether an issue gets media coverage or not, and which actors are able to access the media, achieve and secure coverage (Murdock et al. 2003, Anderson 2006, Boykoff and Boykoff 2007). In-depth analysis of these factors is critically important in assessing the effectiveness of media strategies over time on a particular issue (Anderson 2009).

The media is considered an important tool for maintaining a democratic society as it links the state and the public (Eek and Ellström 2007). When the media is mentioned in the literature, it is often in the context of Western values and norms, with free press and freedom of expression. However, this is not the case in many developing countries such as Vietnam. In Vietnam, mass media takes the form of newspapers, magazines, radio and television, news 
agencies and electronic communications. According to the Vietnam Journalism Association, in August 2010 Vietnam had 706 news agencies and newspaper organisations with a total of 178 print newspapers, 37 online newspapers and 528 magazines; one national radio broadcaster (the Radio Voice of Vietnam); one national television broadcaster (Vietnam Television); and 64 local radio and television stations. Television and radio (national and local) are the most important mediums, and are staterun (Asia New Zealand Foundation 2010).

In Vietnam, all forms of the media are controlled by the government. The role of the media is to spread propaganda about state politics and policies, and to promote patriotism and socialist ideology (Tran 2005, Eek and Ellström 2007, McKinley 2007). Research is lacking on the media in Vietnam, and its influence on public understanding of policy in general (Eek and Ellström 2007, McKinley 2007) and REDD+ related policy in particular. This study is one of very few to address these gaps in the literature.

Since the media in Vietnam is mainly a vehicle of the Party, the results of this media analysis should be interpreted differently from other countries, as the media reflects the position of the Party, rather than a broader diversity of actors.

\subsection{REDD+ in Vietnam}

Vietnam was recognised in the 2007 Conference of the Parties (COP 13) to the United Nations Framework Convention on Climate Change (UNFCCC) as one of the five countries expected to be most affected by climate change, given its long coastline and already pressured natural resources. Reduction of carbon emissions continues to be a government priority (Pearman 2010) although rising sea levels is the highest priority, which is reflected in the national target programme (Clark 2009). The country is an interesting case for investigation owing to its rare trend of increasing forest cover, which makes Vietnam one of the few tropical countries on the right side of the forest transition curve (Hoang et al. 2010). Vietnam has been an active participant in the international climate change arena. The country signed the UNFCCC in 1994 and the Kyoto
Protocol in 2002. In 2009, the country was selected as the first in the world to pilot the United Nations Collaborative Programme on Reducing Emissions from Deforestation and Forest Degradation in Developing Countries (UN-REDD) funded by the Government of Norway. REDD+ has also been integrated in several key legal frameworks, including: the National Target Programme on Climate Change Response for the period 2009-2015; the Action Plan Framework to Respond to Climate Change for Agriculture; and the National Forest Development Strategy (Hoang et al. 2010). The Government of Vietnam emphasises that REDD+ should enhance sustainable forest management, biodiversity conservation and forest carbon stocks, all within current environment and socioeconomic development strategies.

REDD+ is new to Vietnam and national laws and implementing regulations contain gaps and ambiguities that need to be addressed (MARD and UN-REDD 2010). National stakeholders often lack information about REDD+ and addressing this is an essential first step towards building local capacity to effectively engage in REDD+ discussions and decision-making (Pham 2009, Hoang et al. 2010). The national REDD+ process has made remarkable progress but little information is available about assessment of the national programme (Pham 2009). The Ministry of Information and Communications, in collaboration with the Ministry of Natural Resources and Environment, is tasked with raising public awareness and understanding of climate change. However, up-to-date information on how mass media in Vietnam has impacted on public understanding, and on policy implementation on climate change and REDD+ is unknown.

Since the media can potentially help to raise awareness about policy issues, propose specific policy solutions, or broadly advocate for policy action (Boykoff and Boykoff 2007, Anderson 2009), it is one of the key channels to provide news and information about REDD+ to the public (Dung 2008). A close examination of what the media has achieved and what should be improved regarding REDD+ coverage is urgently needed. This study attempts to fill this gap. 


\section{Methods}

This study is a part of a larger project, the Global Comparative Study on REDD+ (GCS-REDD+), which aims to carry out a comparative analysis amongst different countries concerning their stages of REDD+ implementation. The study, therefore, employed a wide range of research methods which were predesigned by CIFOR $(2010 \mathrm{~b})^{2}$.

\subsection{Newspaper and article selection}

Television and radio are the most important broadcasting instruments in Vietnam, which has well-developed national and local networks (Asia New Zealand Foundation 2010). However, the national radio and television channel often use newspapers as their main source of information. This suggests that newspapers are in fact quite influential, which justifies the focus of this study.

To ensure a balanced view and representative sample, we developed and used a set of criteria for newspaper selection. They were: having high national circulation, reflecting a broad spectrum of political positions (although this is limited in Vietnam), and being accessible both in print and online. Thus, the selected newspapers represent much of the information that arrives to the public and policymakers through the printed mass media. The choice of three newspapers was based on comparable media studies, such as COMPON, which selected a similar number. The selection was also limited to three newspapers because the study covers 4 years and we risked being overwhelmed with data, while having limited resources for analysis. Since the focus of the study is the media and the policy process, scientific journals were not selected.
Consultations with representatives from the Ministry of Information and Communications which manage the media, were also conducted to ensure the selection was representative and met the criteria. The three selected newspapers are: Nhân Dân (People), Tuổi Trẻ (Youth Ho Chi Minh) and Nông Nghiệp Việt Nam (Vietnam Agriculture). The mission/ vision, daily circulation, nature and scope of these newspapers are presented in Table 1.

Once we had selected the newspapers, we used the following key phrases (translated from English into Vietnamese) to search for articles concerning REDD+ frames, actors and events covering the period from December 2005, when REDD+ emerged on the international policy agenda at the COP 11 meeting, to April 2010:

- PES

- Chi trá các dịch vu môi truờng (payment for environmental services)

- Chi trả dịch vụ môi triờng rìng (payment for environmental forest services)

- REDD

- Giám phát thải do phá rìng và suy thoái rüng (reduced emissions from deforestation and degradation)

- Giảm phát thải tui mất rüng và suy thoái rüng (Reduced emission from deforestation and degradation)

- Giảm khi phát thải tù việc mất rìng và suy thoái ring (reduced emissions from deforestation and degradation)

- Giảm phát thải khí nhà kinh (reduced greenhouse gases)

- Giảm phát thải (reduced emissions)

2 The methodology for this analysis was adapted by Monica Di Gregorio of the Development Studies Institute, London School of Economics, from the 'Code book for the analysis of media frames in REDD articles' by Stephan Price (University of Kent) and Clare Saunders (University of Southampton), written in 2009 and applied in a policy research programme on climate change, COMPON, led by Jeffrey Broadbent (University of Minnesota). The long-term scientific goal of COMPON is to explain the variation in national response to global climate change under the emerging international regime. Examining the causes of this variation from the perspective of networks of discourse and policy making interaction amongst relevant organisations and knowledge brokers, the project collects empirical data for rigorous comparative analysis. CIFOR's project materials and guidelines with the adapted methodology are expected to be available in early 2011 at www.ForestsClimateChange.org. 
Table 1. Characteristics of newspapers selected

\begin{tabular}{|c|c|c|c|}
\hline & Tuổi Trẻ (Youth Ho Chi Minh) & Nhân Dân (People) & $\begin{array}{l}\text { Nông Nghiệp Việt Nam } \\
\text { (Vietnam Agriculture) }\end{array}$ \\
\hline $\begin{array}{l}\text { Year of } \\
\text { establishment }\end{array}$ & 1975 & 1951 & 1987 \\
\hline Mission/vision & $\begin{array}{l}\text { Safeguarding the public's right } \\
\text { to know. The paper is a broad } \\
\text { tribune gathering creative ideas to } \\
\text { foster the cause of reconstructing } \\
\text { Vietnam, to protect the truth, and } \\
\text { to build a fair and just society. }\end{array}$ & $\begin{array}{l}\text { Disseminating government } \\
\text { policies }\end{array}$ & $\begin{array}{l}\text { Disseminating information } \\
\text { related to the agriculture sector }\end{array}$ \\
\hline Targeted readers & Strong focus on young readers & $\begin{array}{l}\text { Strong focus on government } \\
\text { staff and agencies }\end{array}$ & $\begin{array}{l}\text { Strong focus on farmers, } \\
\text { farmers' associations and rural } \\
\text { development agencies }\end{array}$ \\
\hline Daily circulation & 420000 & 220000 & 70000 \\
\hline $\begin{array}{l}\text { Number of readers } \\
\text { visiting website per } \\
\text { day }\end{array}$ & 4000000 & $800000-1000000$ & 50000 \\
\hline Political affiliation & $\begin{array}{l}\text { Ho Chi Minh Communist Youth } \\
\text { Organisation and Department of } \\
\text { Journalism (Ministry of Information } \\
\text { and Communications) }\end{array}$ & $\begin{array}{l}\text { Party Central Committee and } \\
\text { Department of Journalism } \\
\text { (Ministry of Information and } \\
\text { Communications) }\end{array}$ & $\begin{array}{l}\text { Ministry of Agriculture and } \\
\text { Rural Development and } \\
\text { Department of Journalism } \\
\text { (Ministry of Information and } \\
\text { Communications) }\end{array}$ \\
\hline $\begin{array}{l}\text { Number of } \\
\text { departments within } \\
\text { the newspaper }\end{array}$ & 15 & 19 & 4 \\
\hline $\begin{array}{l}\text { Number of } \\
\text { journalists working } \\
\text { for the newspapers }\end{array}$ & 300 & 312 & 32 \\
\hline $\begin{array}{l}\text { Geographical } \\
\text { coverage }\end{array}$ & National but mainly in the south & National but mainly in the north & $\begin{array}{l}\text { National but mainly in the } \\
\text { north }\end{array}$ \\
\hline $\begin{array}{l}\text { Frequency of } \\
\text { publication }\end{array}$ & Daily & Daily & Daily \\
\hline Format & Print and online & Print and online & Print and online \\
\hline Readership range & $900000-1200000$ & $\mathrm{~N} / \mathrm{A}$ & $\mathrm{N} / \mathrm{A}$ \\
\hline
\end{tabular}

$\mathrm{N} / \mathrm{A}=$ not available

Source: Nhân Dân (2010), Tuổi Trẻ (2010) and 4 international media (2010)

The first four key phrases were selected to comply with CIFOR research design. The next three key phrases concerning payment for environmental services (PES) were selected for two reasons: i) one of the core issues in REDD+ is how to create a multilevel (international and national) PES scheme (Angelsen 2008); ii) PES is seen by the government as an essential component of REDD+ (Pham 2009). The final key phrase, concerning greenhouse gases, was suggested by representatives of the Ministry of Police and the Ministry of Information and Communications.
In total, 62 articles were found that contain these key phrases (See Table 2).

Although 62 articles were found using these key phrases, only 18 (29\%) of these articles actually discussed REDD+ (see Table 3).

\subsection{Coding and media framing}

The 18 articles discussing REDD+ were analysed using a media content analysis tool for investigating media discourse, based on a predefined codebook. 
Table 2. Results of key phrase search

\begin{tabular}{|c|c|c|c|c|}
\hline Key phrases & $\begin{array}{c}\text { Tuổi Trẻ } \\
\text { (Youth Ho Chi Minh) }\end{array}$ & $\begin{array}{l}\text { Nhân Dân } \\
\text { (People) }\end{array}$ & $\begin{array}{l}\text { Nông Nghiệp Việt Nam } \\
\text { (Vietnam Agriculture) }\end{array}$ & Total \\
\hline PES & 0 & 1 & 0 & 1 \\
\hline $\begin{array}{l}\text { Chi trả các dịch vụ môi trường (payment for } \\
\text { environmental services) }\end{array}$ & 0 & 0 & 0 & 0 \\
\hline $\begin{array}{l}\text { Chi trả dịch vụ môi trường rừng (payment for } \\
\text { environmental forest services) }\end{array}$ & 6 & 3 & 2 & 11 \\
\hline REDD & 1 & 4 & 2 & 7 \\
\hline $\begin{array}{l}\text { Giảm phát thải do phá rừng và suy thoái rừng } \\
\text { (reduced emissions from deforestation and } \\
\text { degradation) }\end{array}$ & 0 & 0 & 0 & 0 \\
\hline $\begin{array}{l}\text { Giảm phát thải từ mất rừng và suy thoái rừng } \\
\text { (reduced emission from deforestation and } \\
\text { degradation) }\end{array}$ & 0 & 0 & 0 & 0 \\
\hline $\begin{array}{l}\text { Giảm khi phát thải từ việc mất rừng và suy thoái } \\
\text { rừng (reduced emissions from deforestation and } \\
\text { degradation) }\end{array}$ & 0 & 0 & 0 & 0 \\
\hline $\begin{array}{l}\text { Giảm phát thải khí nhà kính (reduced greenhouse } \\
\text { gases) }\end{array}$ & 10 & 17 & 0 & 27 \\
\hline Giảm phát thải (reduced emissions) & 6 & 9 & 1 & 16 \\
\hline Total & 23 & 34 & 5 & 62 \\
\hline
\end{tabular}

Table 3. Number of articles on REDD+

\begin{tabular}{lccc}
\hline & $\begin{array}{l}\text { Tuổi Trẻ } \\
\text { (Youth } \\
\text { Ho Chi } \\
\text { Minh) }\end{array}$ & $\begin{array}{c}\text { Nhân Dân } \\
\text { (People) }\end{array}$ & $\begin{array}{c}\text { Nông Nghiệp } \\
\text { Việt Nam } \\
\text { (Vietnam } \\
\text { Agriculture) }\end{array}$ \\
$\begin{array}{l}\text { Number of } \\
\text { articles for all key } \\
\text { phrases }\end{array}$ & 23 & 34 & 5 \\
$\begin{array}{l}\text { Number of } \\
\text { articles related } \\
\text { to REDD+ }\end{array}$ & 7 & 7 & \\
\hline
\end{tabular}

'Discourse' is defined by Tuula (2010) as 'contextually embedded national policy debate components of which political actors constitute the broader storylines'. Discourse analysis based on this definition highlights various actors and their views toward an issue or policy.

Media content analysis is undertaken through identification of media or news frames. 'News frames' refer to the principles of selection, emphasis, and ways of organising controversial ideas into meaningful categories (Entman 1993, Miller and
Riechert 2000). Frame is described as 'the main understanding or interpretation of REDD+ as it is presented in the article'.

The coding process was based on a codebook organised in three levels. Level 1 captured descriptive variables only, including date and author, the length of the article, what day of the week it ran, and the section of the newspaper it appeared in. While largely used for identification purposes, level 1 coding can also indicate shifts in the priority placed on REDD+ coverage in the media.

Level 2 coding compiled broad variables about the media frames. While many articles provide one single frame or interpretation of central issues, longer articles might have two or more frames. The coding identified the primary and, where applicable, the secondary frames. The primary frame is usually found in most prominent elements of the text: the headline, subheading and first paragraph. The primary frame is also likely to quote sources in support of the frame; these are more likely to be named, and more likely to be prestigious, than in subsidiary frames. Once the 
elements of the text that support the primary frame have been eliminated, the remaining text is grouped into themes. These themes are assessed according to their position in the text and the nature and extent of quoted sources to identify a secondary frame.

Identifying the primary and secondary frames also enables assessment of the comparative importance given to different understandings of a topic by journalists and editors (Boykoff 2008). Shorter articles are less likely to consist of more than one frame (Boykoff 2008). Most of the articles identified by the selection criteria do not have a secondary frame. The average word count per article is 500 words (the shortest article was 83 words and the longest 1960 words). Level 2 coding also identified the type of frame (e.g. diagnostic, prognostic, symptomatic or motivational); the political scale at which it framed the debate (e.g. international, national or subnational); and the specific topics around which it framed the debate (political, economic, ecological, etc.).

Level 3 coding identified the primary and secondary frames in much more detail. It included identification of the main advocates and adversaries of the frame, their particular stances (statements where they express their position on issues related to REDD+), and their assessments of likely future REDD+ outcomes. An advocate of the frame is an actor that is mentioned in the article who proposes or supports the specific frame (the main understanding or interpretation of REDD+ as it is presented in the article). The adversary is an actor that is mentioned in the article who opposes this specific frame. This is independent from supporting or being opposed to REDD+ itself. Apart from the analysis of the frame, the coding recorded all mentions of protest events, policy events and any other actors mentioned in the articles.

\subsection{Key informant interviews}

A number of studies have conducted interviews with journalists in developing countries who report on climate change (e.g. Mormont and Dasnoy 1995, Wilson 2000, Harbinson et al. 2006, Boykoff and Mansfield 2008). However, research exploring the perspectives of journalists and media professionals in developing countries is limited (Harbinson et al.
2006, Anderson 2009). To address this gap and to complement the coding process, in-depth interviews were conducted with nine selected journalists. The criteria for interviewee selection were those journalists who:

- have an interest in REDD+ in particular and in environmental issues in general;

- have written articles on REDD+;

- work in different geographical areas of Vietnam;

- are willing to participate in this study.

Since television and radio are two powerful forces in Vietnam, we interviewed not only daily print media, but also representatives of television (VTV1 and VTV2) and national radio (VOV). Also, to understand both formal and informal media networks that exist in Vietnam, we interviewed a representative of civil society. The transcripts were then coded to ensure the anonymity of interviewees.

The aim of these interviews was to understand the aspects of the debate covered by the media in Vietnam, the actors that influence the debate, sources of information that journalists used, opportunities and constraints for the journalists and reporters to write about REDD+, possible solutions to these constraints, and support the interpretation of the survey data. These interviews were conducted between May and August 2010.

\subsection{Es framework}

The media frame was also coded according the main concern of the advocate and adversary with respect to effectiveness, efficiency and equity (3Es) aspects of REDD+. The 3Es approach to assessing REDD+ was proposed by Angelsen (2008). This approach looks at:

- Effectiveness: Can REDD+ policy help reduce emissions from deforestation and forest degradation? This depends on the commitment of countries and the design of REDD+ policies and implementation. Measures of effectiveness are indirect and need to take into account additionality, leakage and permanence.

- Efficiency: Is REDD+ provided at the minimum cost (minimum transaction cost with the payment scheme covering the opportunity costs of environmental service providers)? Costs include start-up costs, operational costs, opportunity cost from alternative land uses and transaction costs. 
- Equity: Are benefits and costs distributed fairly amongst stakeholders? Can the poor access payments and benefit from the policy? Are rights protected? It includes fair distribution between and within countries, effects on indigenous communities and the existence and distribution of co-benefits, which usually includes the potential for poverty reduction, biodiversity conservation and governance, and protection of rights.

The stance of each advocate and adversary was evaluated according to whether it placed a priority on any of the 3Es. 


\section{Results}

\subsection{Existing discourses and how they shape the national REDD+ arena}

\subsubsection{Overview of climate change and REDD+ coverage}

Media coverage is often measured by its quantity, prominence, and frequency (Crow 2010). To assess REDD+ coverage in Vietnam, these factors are all analysed in the following section.

Climate change first received international media coverage in a publication called Modern Mechanics in 1932 (Blog.modernmechanix 2006) by Climate change and REDD+ has only been reported on since late 2007 in Vietnam. In that year, REDD+ was only covered in Tuổi Trẻ (Figure 1). The interviewee from Tuổi Trẻ explained that 'we only started to learn about REDD and climate change as important global discussions during COP13'. Poor language skills and a low level of environmental awareness amongst journalists were mentioned by most interviewees as reasons for late coverage of REDD+ in Vietnam.

Despite the late introduction of these issues in Vietnam's print media, the number of articles on 'climate change', and 'climate change and forests' has increased significantly over time. The number of articles found for 2009 was four to five times larger than can be found for the previous year. Since the articles were only searched up to April 2010, it is not valid to discuss the decrease in that year. This increase was explained by interviewees as partly the result of increasing understanding of these issues amongst journalists and partly because the government was active in several international initiatives related to climate change. Dung (2008) also found that the increase in the number of articles can be attributed to the fact that the Ministry of Natural Resources and Environment was more active in disseminating information on climate change, and media leaders were more supportive of environmental journalism.

To understand the role of the media it is important to look at media coverage and policy cycles together. One of the crucial functions of the media is that it can define the saliency of public policy issues. In this respect media coverage can translate into the placement of policy issues on the political agenda (Crow 2010). The policy cycle is usually analysed as linear sequences of agenda setting and policy adoption. However, if instead the focus is on policy change, this often reveals multiple decision-making points of new policies, and overlapping processes where decisions at any one time might affect much

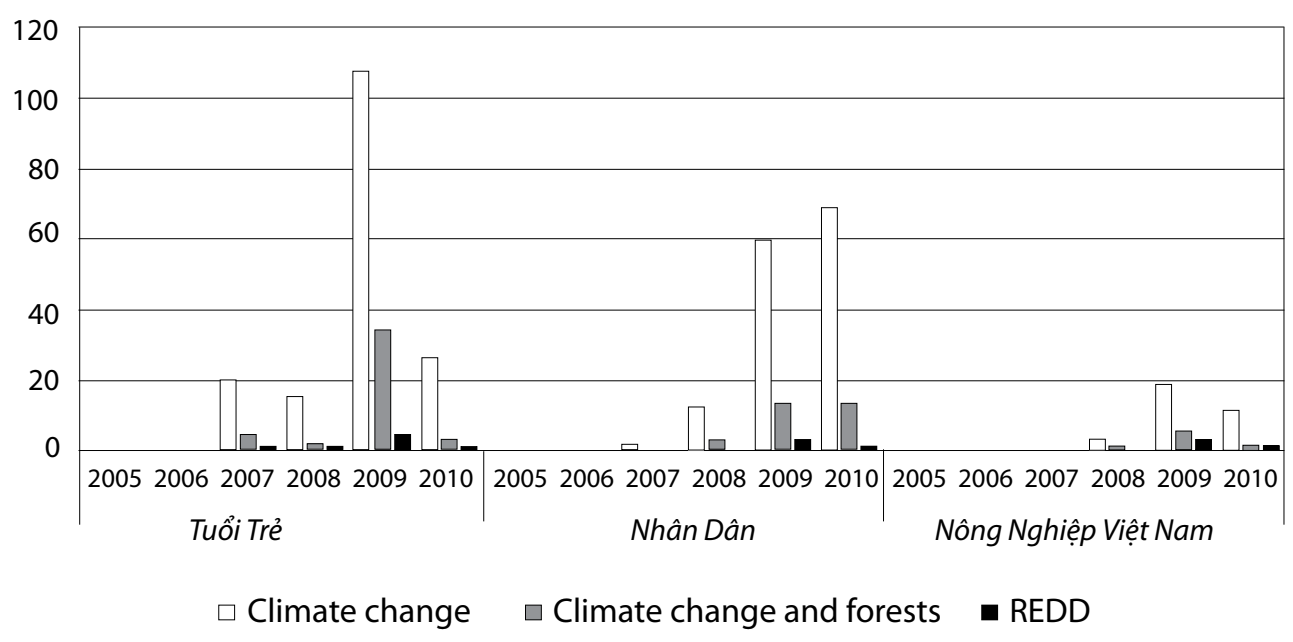

Figure 1. Frequency of articles 2005-2010 
later developments (Crow 2010). Figure 1 indicates three distinct increases in REDD+ media coverage in Vietnam, which is supported by the interviews. The first rise was in 2007, when the Conference of the Parties (COP13) first brought this issue to prominence. A Tuổi Trẻ article mentioned COP13 and predicted a promising future for REDD+ with the headline 'International conference on climate change in Bali-Protecting forests will be rewarded billions of US\$'. The author (Thanh Tuan) also argued in this article that 'REDD+ provides the right incentives for developing countries to pay more attention to forest protection and reforestation'.

The second rise came in 2008 with several new national policy events related to REDD+, such as approval of the Action Plan Framework for Adaptation and Mitigation of Climate Change of the Agriculture and Rural Development Sector 2008-2020, the National Action Plan for Adaptation and Mitigation of Climate Change and Decision 380/QD-TTg on piloting payments for forest environmental services. Articles in 2008 ( 2 out of 18 articles) informed the public about these policies, although the approaches were slightly different between newspapers. As the government mouthpiece, Nhân Dân directly addressed these policies with the article, 'From January 2009, piloting payment for forest environmental services'. The other article, in Tuổi Tré, referred to the same issues, but caught the reader's attention with a more interesting title: 'Eat forests, pay for forests'.

The peak in coverage of REDD+ was in 2009 (10 out of 18 articles), which was directly related to three policy events: the implementation of Decision 380/QD-TTg (3 articles); the launch of the United Nations Collaborative Programme on Reducing Emissions from Deforestation and Forest Degradation in Developing Countries (UNREDD) (3 articles); and COP15 (3 articles). In this year, coverage continued to increase substantially leading up to and during COP15. These three events generated a significant amount of news media coverage and the surge of interest was relatively longlived as they continued to be discussed in 2010 . Within this media attention, the following questions related to Decision 380/QD-TTg arose: Why is Decision 380/QD-TTg important? How is it being implemented?
The three newspapers studied also approached REDD+ in different ways in 2009. Nhân Dân performed its role as a government organ by informing the public about Vietnam's role in international politics, with articles such as: 'Prime Minister Nguyen Tan Dung: There is a need for collaboration amongst all countries to combat climate change'; 'Prime Minister Nguyen Tan Dung visited Russia and attended the climate change conference in Denmark'; and 'Draft Copenhagen agreement is opposed'. The last two of these articles were published on the same day (14 December 2009) which clearly highlights the government's interest in and concerns about COP15. Targeting a more general audience, Tuổi Trẻ covered a wide range of issues including: ecological discussions with 'Poor forests'; informing readers about progress with UN-REDD in 'Vietnam makes an effort in joining UN-REDD'; and implementation of Decision 380/ QD-TTg with 'Hydropower plants pay for forest protection' and 'TPHCM-the price of clean water is increased $40 \mathrm{VND} / \mathrm{m}^{3}$. Nông Nghiệp Việt Nam provided sectoral information with 'Forum on Forest Carbon Partnership' and 'United Nations supports Vietnam in reducing deforestation'. It also discussed Decision 380/QD-TTg in 'Payments for forest environmental services-who benefits?'

In 2010, the three selected newspapers continued their discussions on Decision 380/QD-TTg (3 out of 5 articles) from different perspectives. Nhân Dân emphasised the need to 'Accelerate payment for forest environmental services'. Nông Nghiẹp Việt Nam stated 'Payments for environmental forestry services - the responsibilities cannot be ignored'. Tuổi Trẻ asserted 'Those who benefit from forests will have to pay the fee'. Nhân Dân continued to act as a key government mouthpiece and was the only one of the three newspapers to discuss and disseminate information related to the international debate on REDD+ with two articles: 'Priorities of the United Nations in 2010 ' and 'Development of a green economy'.

Although the search was only conducted up to April 2010 , that year saw an increase in coverage compared with 2005 and 2007. Of the 18 articles identified as relevant, Tuổi Trẻ and Nhân Dân had 7 articles each on REDD+ while Nông Nghiẹp Việt Nam had only 4. As illustrated in Table 1, the three selected papers represent different areas of the social and political 
spectrum in Vietnam. Tuổi Trẻ represents general and young readers. Nhân Dân represents the voice of the government and Nông Nghiẹp Việt Nam represents the voice of the agriculture and forestry sector.

\section{Interestingly, both Nhân Dân and Nông Nghiẹpp} Viẹt Nam were late in informing their readership about REDD+ (not until 2009) compared with Tuôi Tré, which began coverage of REDD+ in 2007. Interviewees from Nhân Dân claimed that since the newspaper was a government instrument, it only publishes articles showing the positive impact of policies and national programmes. Thus, until a policy like REDD+ has been confirmed by the government as the right direction to move in, the paper will not discuss it. The interviewees also claimed that Nhân Dân only considers publishing new information if other national newspapers also cover it. Few national newspapers discussed REDD+ before 2009, so the Nhân Dân editorial board did not see the need to inform public about this issue. The interviewee from Nông Nghiẹp Việt Nam asserted that although the newspaper represents the agriculture and forestry sector it was late in covering

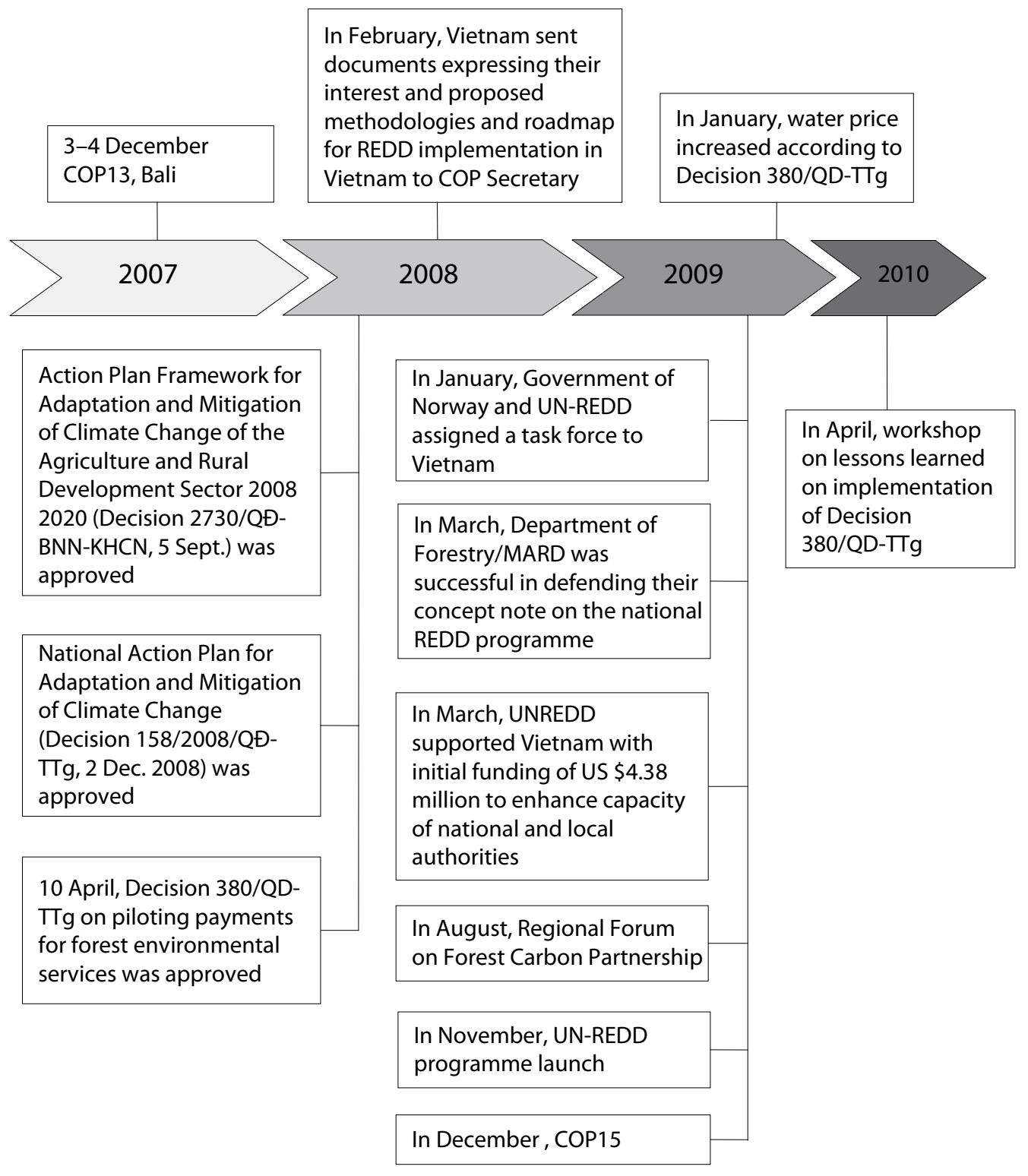

Figure 2. Policy events reported in the media which have influenced REDD in Vietnam 
REDD+ because its vertical management agency, the Ministry of Agriculture and Rural Development (MARD), was only assigned as a focal point for REDD+ in 2009. This would suggest that coverage at the national level occurs only in conjunction with major international and national policy events. Furthermore, of the three, Nông Nghiệp Viẹt Nam has the least number of articles on climate change and REDD+.

According to key informants, this is partly because the journalists working for Nông Nghiệp Việt Nam do not have an environmental or forestry background and have a poor understanding of REDD+. Thus, they only reported on REDD+ when MARD organised a related workshop.

\subsubsection{Scale and level of the debate}

The frames of 7 out of 18 articles on REDD+ were international, while 11 were national and subnational (Figure 3).

The scale of frames shifted over time, from only discussing the issues at an international level in 2007 to more national and subnational discussion from 2008 (Figure 4). The most salient news-grabbing event of 2010 was Decision 380/QD-TTg, which was preceded by heavily politicised moves to join the global effort to combat climate change and reduce deforestation.

Those articles with an international frame discuss COP 13 and COP 15 and raise comments by policy makers, leading officials and diplomats. These conferences stimulated the media to pay more attention to the role of Vietnam in international negotiations and were high points in the coverage of
REDD+. Despite much of the news being framed at a national level in 2009, the reporting of COP 15 was prominent, and discussed the position of the Vietnamese government during the event. The media also reported on international commitments to support REDD+ in Vietnam. Interviews were also published with the UN Secretary General UNREDD programme leaders, the Vietnamese Prime Minister Nguyen Tan Dung and with the Minister of Natural Resources and Environment.

These articles discussed the international importance of climate change and REDD without linking the issues to the national context. This was confirmed by interviewees, who claimed that the media in Vietnam does not have enough information and knowledge to discuss REDD in the national economic, political and environmental context.

Figure 5 shows the proportion of reporting on significant REDD+ policy events in Vietnam: the annual United Nations Framework Convention on Climate Change (UNFCCC) Conference of the Parties (27\%); UNREDD in Vietnam (17\%); and the approval of Decision 380/QD-TTg (38\%). This also shows a rapid transition from reporting only international events in 2007 to mainly domestic events in 2008 and 2009. This shift is interesting since it is different from the results of media analyses in other countries such as Indonesia (Cronin and Santoso 2010) and Bolivia (Videa 2010) which mainly focus on the international debate.

\section{Decision 380/QD-TTg and media coverage}

It is crucial to establish a payment for environmental services (PES) scheme and a benefit sharing distribution system, to ensure the success and

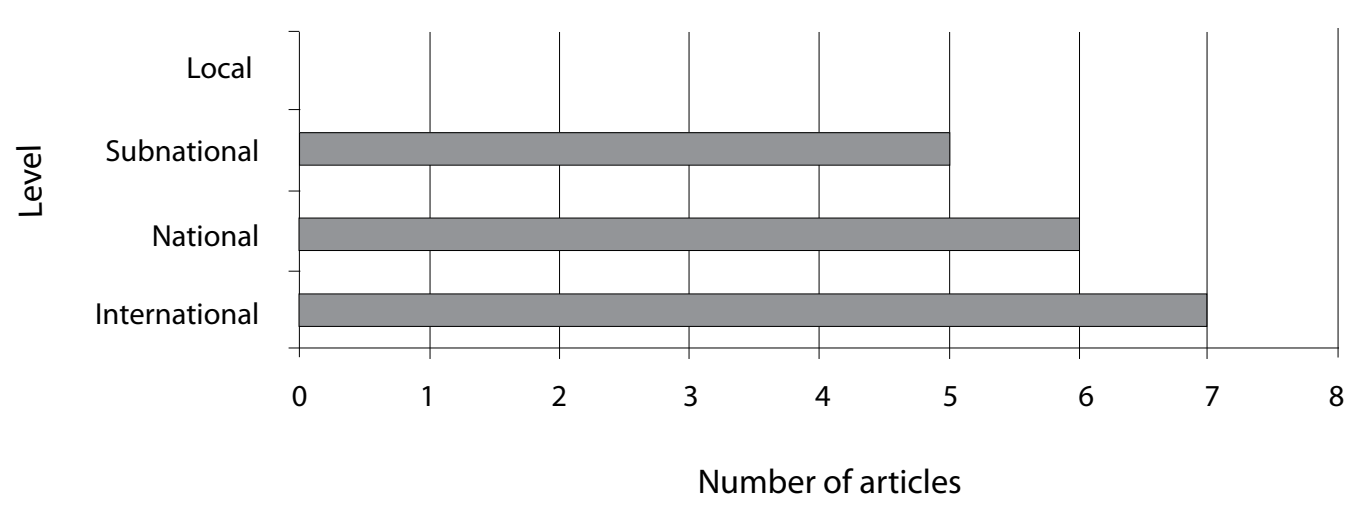

Figure 3. Level of debate in articles on REDD+ 


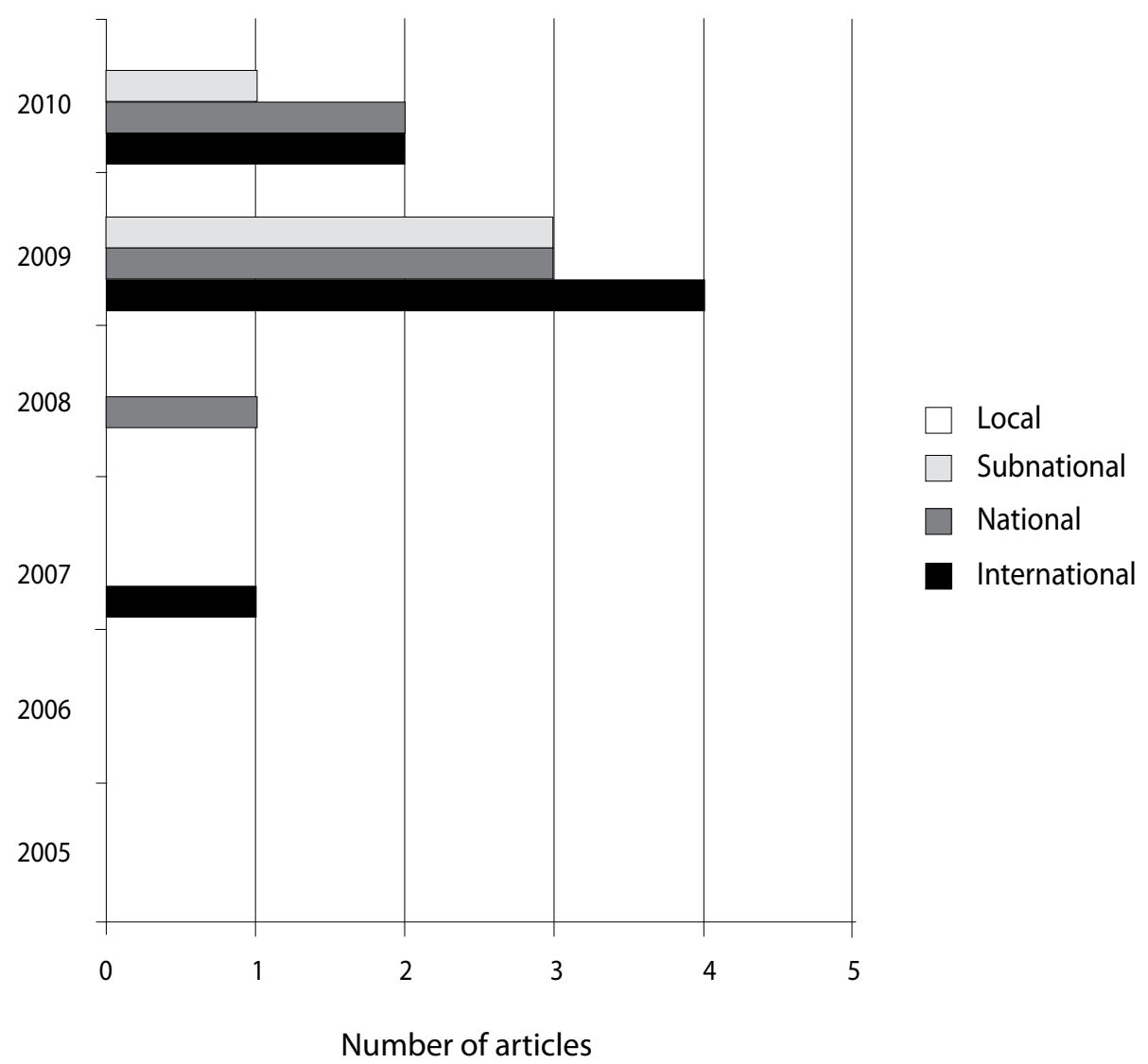

Figure 4. Scale of REDD+ discussion 2005-2010

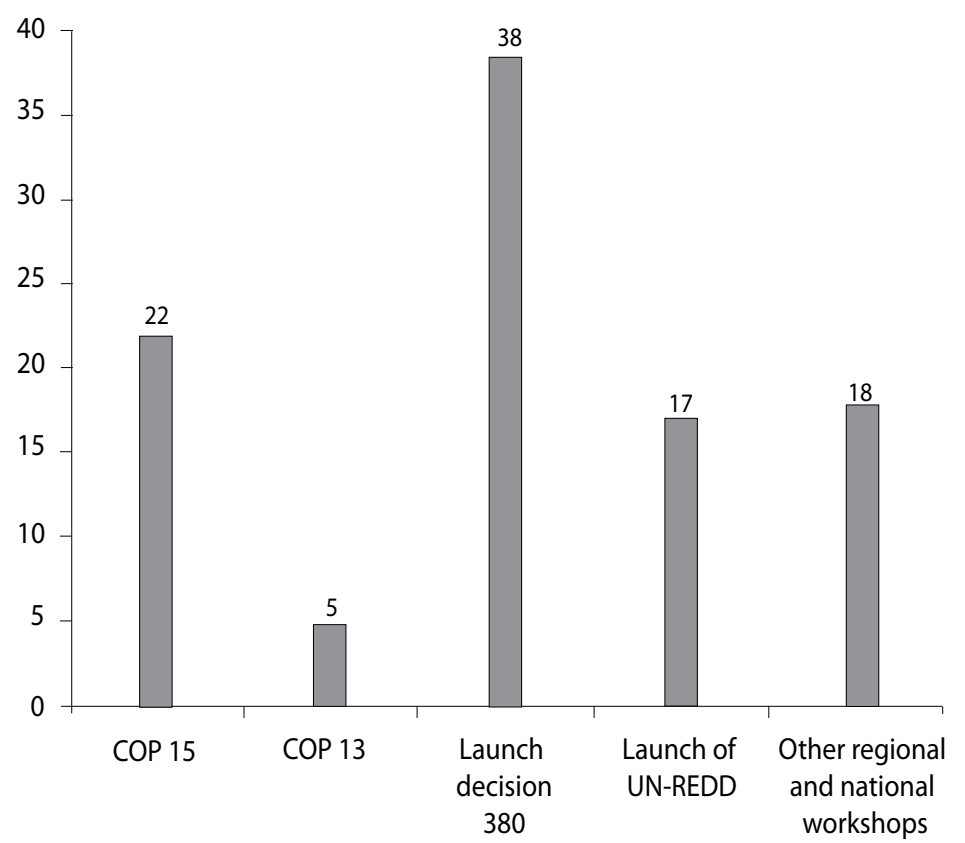

Figure 5. Percentage of articles associated with key REDD+ events

sustainability of REDD+. Decision 380/QDTTg, approved in 2008 by the prime minister, is considered a milestone for development of PES schemes to protect forests in Vietnam. Since one of the core issues in REDD+ is how to create a multilevel (international and national) PES scheme 
(Angelsen 2008), the government of Vietnam has made this a priority. This decision established pilot PES projects in Lam Dong, Dong Nai, Ninh Thuan, Binh Thuan, Son La and Ho Chi Minh City during 2008-2009.

According to Decision 380/QD-TTg, forest owners will receive payments based on the following calculation:

Amount paid to forest owner (VND) = Average fee/ha of forest (VND/ha) $x$ forest area managed for services (ha) $x$ Coefficient $\mathrm{K}$

Where:

a. The average fee per hectare of forest (VND/ha) is the total received from environmental service users, less the management costs of provincial authorities, divided by the total area of forest in the catchments as approved by the agency responsible for the PES agreement.

b. The forest area that is managed for environmental services includes allocated forest areas, rented areas, and contracted areas.

c. Coefficient $\mathrm{K}$ depends on the forest categories managed (protection forests, special use forests, production forests), the forest status (rich, medium, poor, restoration forest), and the forest history (natural forest, plantation) — as based on the judgement of the provincial people's committee.

Currently, the targeted buyers are hydropower plants and water supply companies in these pilot provinces. These environmental service buyers have to pay 20 VND per kilowatt hour of electricity produced and $40 \mathrm{VND}$ per cubic metre of water supplied. The enforcement of this decision, the level of payment, and the resulting increase in water prices were the main issues raised accounting for 38\% of the debate in event-related articles. However, only about $29 \%$ of the articles on Decision 380/QD-TTg discussed the responses and opinions of service buyers. No articles discussed the service sellers' perspective, nor the level of payment they are receiving and its potential impact on the poor, although various scientific researchers have expressed their scepticism about low payments and high transaction costs of the scheme (Pham et al. 2008).

\section{UNREDD and media coverage}

Vietnam was selected as 1 of 9 UNREDD pilot countries. The programme was launched in Hanoi on 17 September 2009. Funded by the Government of Norway, Vietnam's US $\$ 4.38$ million UNREDD programme will be executed by MARD, and will run for almost two years. The UNREDD programme in Vietnam, now in its implementation phase, seeks to address deforestation and forest degradation through capacity building at national and local levels. Firstly, it will build capacity at the national level to permit the government, and especially the REDD+ focal point in the Department of Forestry, to coordinate and manage the process of establishing tools to implement a REDD+ programme. Secondly, it will build capacity at local levels (provincial, district and community) through pilot schemes in two districts in Lam Dong province that demonstrate effective approaches to planning and implementing measures to reduce emissions from deforestation and forest degradation. These UN-REDD pilot schemes have adopted the procedures and payment schemes established by Decision 380/QD-TTg.

Of the event-related articles, $17 \%$ discuss UNREDD, but are descriptive only and do not assess the programme. Discussions of REDD+ at both the international and national level focused on specific geographical areas where REDD+ is being piloted or is the focus of global debate. At the international level, Indonesia, Denmark and the United States are frequently cited. At the national level, REDD+ discussion focuses on Lam Dong and Son La provinces. Local newspapers did not cover REDD+ in areas which have no forests, which clearly shows a limited understanding of the role of forests. One editor argued thus: 'People will not be interested in REDD as we do not have forests in our area. Therefore, we do not see the importance of raising the issues of REDD in our newspaper.'

The interviews with journalists indicated that those who are based locally but work for national newspapers have a better understanding of REDD+ and can link the international concept with the local context better than journalists who only know REDD+ through the international media and workshops. 


\subsubsection{Sources of stories for print media}

Dung (2010) found that government officials are the main sources of climate change information for the media. Interviews with key informants also showed that government representatives are the main sources of information on REDD+ for journalists. International media and nongovernmental organisations (NGOs) are also key sources of information on REDD+. Although the government plays the central role in providing information for the media, the journalists interviewed also acknowledge technical workshops, international media, scientific reports and civil society as important and useful channels of information about REDD+ (Table 4).

While Borton (2005) expressed concern about press freedom in Vietnam, it is interesting that local people and readers are also appreciated by journalists as an important source of information. One third of the articles on REDD+ in Tuôi Trẻ were written by readers. These readers, however, were retired government staff in a formal research institute so their opinions were in line with those of the government.

\subsubsection{The nature of media coverage of REDD+}

Dung (2010) emphasises that climate change in Vietnam is always linked to certain environmental topics. The most commonly discussed of these topics in the newspapers are water problems, including rising sea levels (25\%), and waste management, including inappropriate use of energy $(22 \%)$, while forests only account for about $11 \%$. These findings are consistent with our data analysis, which shows that the number of articles referring to climate change and forests, and to REDD+ is relatively low compared with those referring to other climate change issues (Figure 1). The number of articles related to climate change and forests only accounts for $21-25 \%$ of identified articles and the number of articles discussing REDD+ is even less (from 4\% in Nhân Dân to $12 \%$ in Nông Nghiệp Việt Nam). Interview results also show that climate change in Vietnam is mainly associated with rising sea levels. This explains why the number of articles on REDD+ has only changed slightly over time, while the number of articles on climate change and forests has increased sharply.
Table 4. Sources of information about REDD+

\begin{tabular}{lcc}
\hline & \multicolumn{2}{c}{ Frequency } \\
\hline Source of information & As ratio & As percentage \\
\hline Technical workshops & $7 / 9$ & 77 \\
\hline International media & $4 / 9$ & 44 \\
\hline Government representatives & $9 / 9$ & 100 \\
\hline $\begin{array}{l}\text { Informal sources such as } \\
\text { personal contacts }\end{array}$ & $1 / 9$ & 11 \\
\hline $\begin{array}{l}\text { Research institutes (universities, } \\
\text { research centres) }\end{array}$ & $1 / 9$ & 11 \\
\hline Local people and readers & $3 / 9$ & 30 \\
\hline Other national newspapers & $5 / 9$ & 55 \\
\hline Other television channels & $1 / 9$ & 11 \\
\hline Scientific reports & $3 / 9$ & 30 \\
\hline Nongovernmental organisations & $4 / 9$ & 44 \\
\hline $\begin{array}{l}\text { Personal reflection and } \\
\text { information }\end{array}$ & $1 / 9$ & 11 \\
\hline Business enterprises & $1 / 9$ & 11 \\
\hline & & \\
\hline
\end{tabular}

It is interesting that when the author first contacted journalists to arrange interviews on REDD+, all interviewees declined because they claimed that they did not know anything about the topic. However, when the author changed the focus of the meeting from 'REDD+' to 'climate change' and 'forests', all of the interviewees were confident to participate.

This, perhaps, reflects government orientation in addressing climate change. Vietnam's Institute of Strategy and Policy on Natural Resources and Environment (2009) emphasised that the government is integrating options for climate change mitigation and adaptation in all its socioeconomic development plans and activities, with special consideration of the impacts of rising sea levels on coastal infrastructure and the livelihoods of coastal communities. Responding to climate change, especially to rising sea levels, is considered crucial to attaining sustained socioeconomic development (Dung 2009).

The interviewees pointed out three impediments resulting in limited REDD+ coverage in Vietnam. 


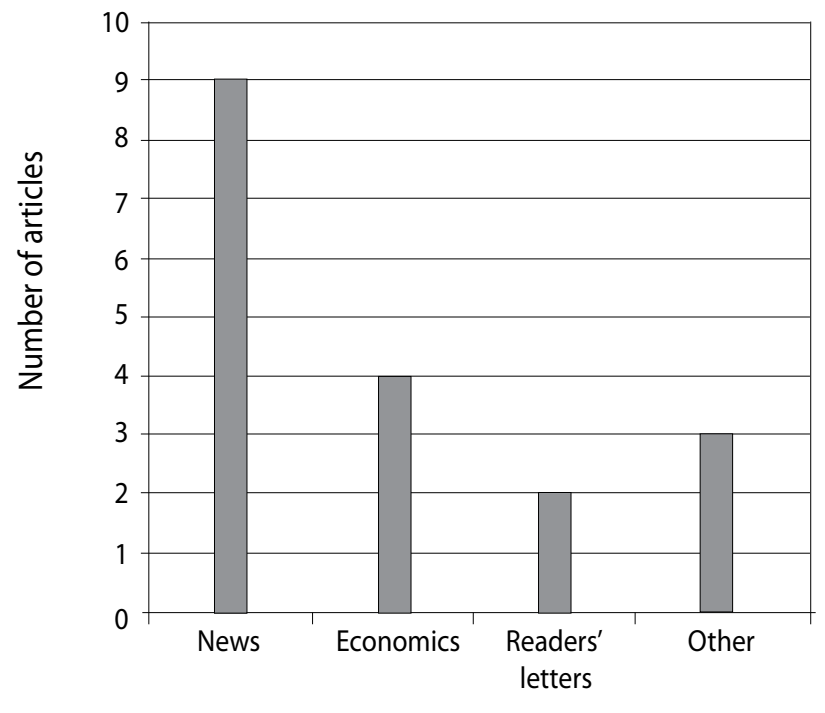

Newspaper sections

Figure 6. REDD+ placement in newspaper sections

First, as Anderson (2009) pointed out, media coverage can be strongly influenced by everyday organisational routines, professional norms, and social factors in the production of news. All interviewees agreed that the current organisational and institutional structure of Vietnamese newspapers provides little room for the journalists to write about REDD+. They stated that their newspapers have no environmental units because environmental issues are not considered as important as economic development. Even when the newspapers featured environmental debates, the issues were analysed from social and economic perspectives, and most articles on REDD+ were thus placed in the news sections $(83 \%)$ or economics section (40\%) (Figure 6).

Furthermore, $66 \%$ of journalists interviewed also claimed that REDD+ has to compete with other 'hot' issues that have a more direct impact on readers. According to one interviewee: 'The newspaper is aware of the importance of the environment in general and REDD+ in particular and has devoted attention to this area since 2007. However, the newspaper has only covered environmental issues such as water pollution and waste, which have a direct link to and impact on people because these topics are of interest to the readers-not forests. The newspaper, if it wants to sell, needs to cover what its readers want to read and REDD+ simply is not an attractive topic for the newspaper's editorial board and readers. As a result, the topic got limited attention.'
The interviewees also claimed that institutional practices in the newspapers also impeded them to write about REDD+. One interviewee told us: 'As journalists, we have to cover many topics and are often directed by the newspaper editor and boards on the issues that we need to cover. Therefore, we cannot focus on environmental topics nor can we choose what we write about. Whether REDD can be discussed in the mass media really depends on the editors. However, since REDD is a new topic, our editors are often not interested in it.'

Secondly, interviewed journalists claimed that they had difficulties in assessing information on REDD+, which affected both quality and quantity of articles on the topic. Of interviewees, $30 \%$ claimed that language barriers to accessing international sources of information and difficulties in arranging meetings with policy makers in charge of national REDD+ programmes are the main obstacles. About $44 \%$ of interviewees commented that REDD+ was often presented by scientists and policy makers in a 'dry' and overly technical manner, which was difficult for journalists to access. 'Journalists often do not understand the technical issues of REDD+ or environmental issues in general, and too often they are given overly technical information by government representatives or project staff,' an interviewee claimed.

Thirdly, about $23 \%$ of interviewees indicated that limited funding available for journalists to attend key events on REDD+ also affected REDD+ coverage. 'All newspapers in Vietnam want to send their journalists and reporters to important events on REDD but they do not have the funds. Moreover, REDD is often discussed for several days and in many sessions in COP meetings. However, we can only afford to stay for the first two days; hence, we cannot get an up-to-date and in-depth understanding of REDD to report on,' an interviewee said.

Media coverage and how it frames policy issues is important for policy outcomes. The media can influence policy agendas by portraying an issue in a positive or negative light; the opinions of readers may be influenced by this (Crow 2010). In Vietnam political interest in REDD+ is based on PES, and is seen through the lens of taxes and fees (Pham $e t$ al. 2008). This political position was discussed in all three selected newspapers. Articles on REDD+ 
were predominantly framed around issues related to politics and policy making (66\%, 12 articles). Of these, $42 \%$ (5 articles) had an international focus, $33 \%$ ( 4 articles) a national focus and 25\% (3 articles) a subnational focus. Most articles were related to international discussions on the importance of REDD+ and the need to enforce Decision 380/QDTTg in the country. Economics and markets were the primary frames for $17 \%$ of articles ( 3 articles) (33\% at international level, 33\% at national level and $33 \%$ at subnational level). These related to potential funding for forest protectors from various international sources (1 article) and the impact of REDD+ on business operations, particularly hydropower plants in Vietnam (2 articles) (Figure 7). Ecology was the primary frame for only 2 articles, which discussed deforestation, definitions of 'poor' and 'rich' forest, and the importance of conserving forest biodiversity in Vietnam.
'Politics and policy making' was the main focus of articles on REDD+ during the period 2008-2010 while 'economics and markets' were only discussed in 2007 and 2010. Data show that news articles on REDD + in Vietnam were predominantly focused on the enforcement and implementation of Decision 380/QD-TTg and its impact on water price increases, and on Vietnam's efforts to implement the UN-REDD programme. In addition, headlines with an urgent tone, calling for support for payments for forest protection were found in 4 out of 18 articles. 'Ecology' not only had the least number of articles but was only discussed in 2009 (Figure 8).

'Politics and policy making' and 'economics and markets' were also covered at international, national and subnational levels, while 'ecology' was only discussed at a national level (Figure 9).

For this study, the frames were coded both in terms of broad metatopic and more detailed subtopics.

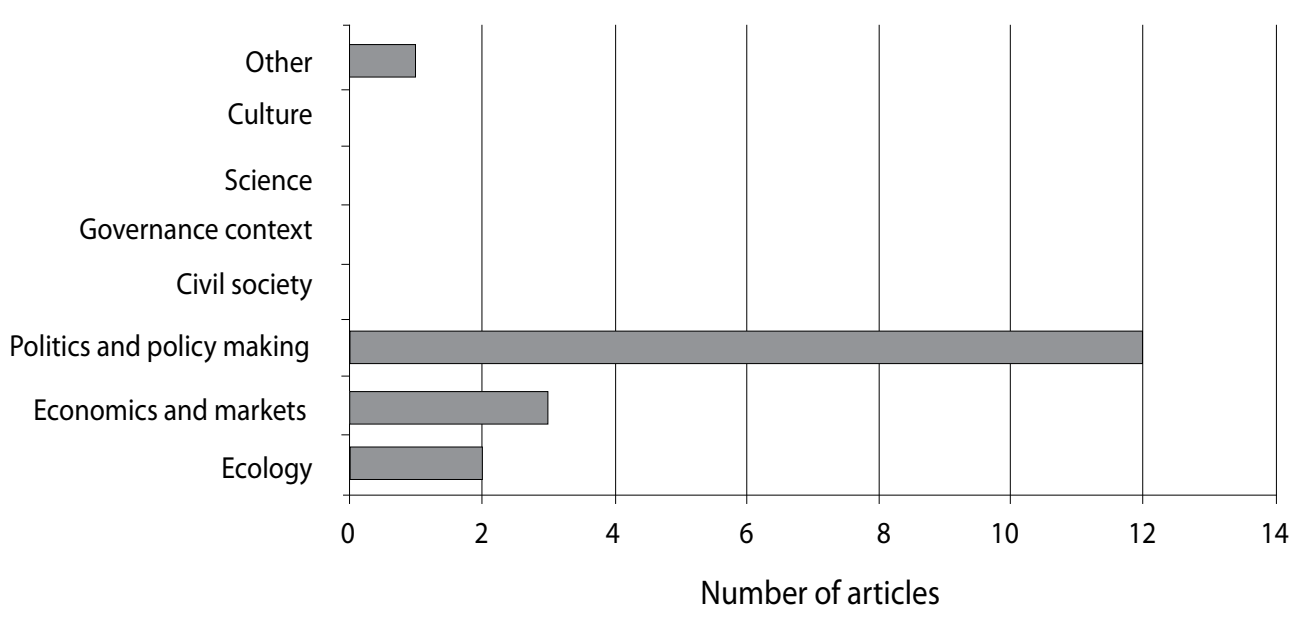

Figure 7. Metatopics

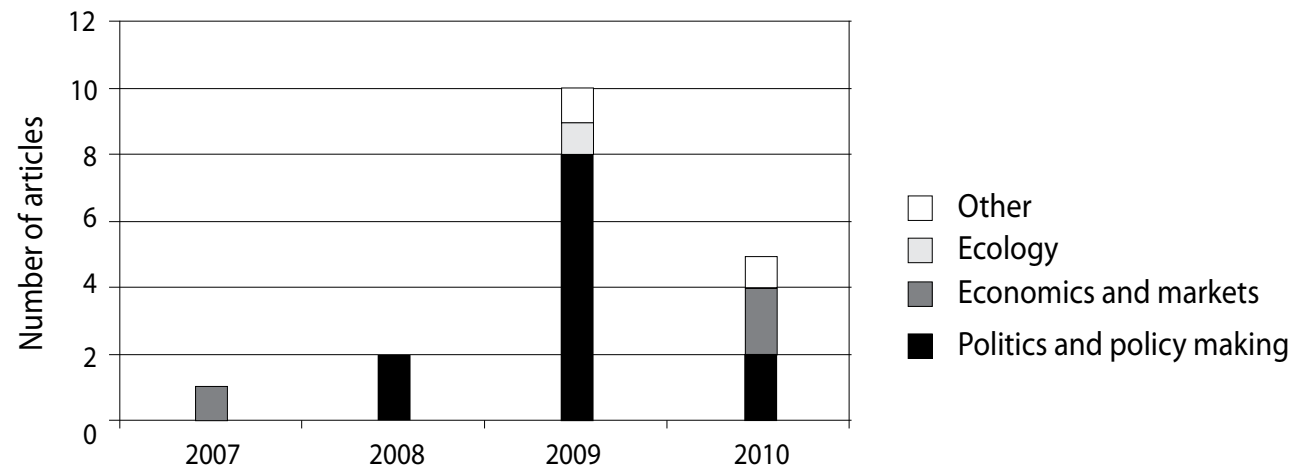

Figure 8. Metatopics by year 


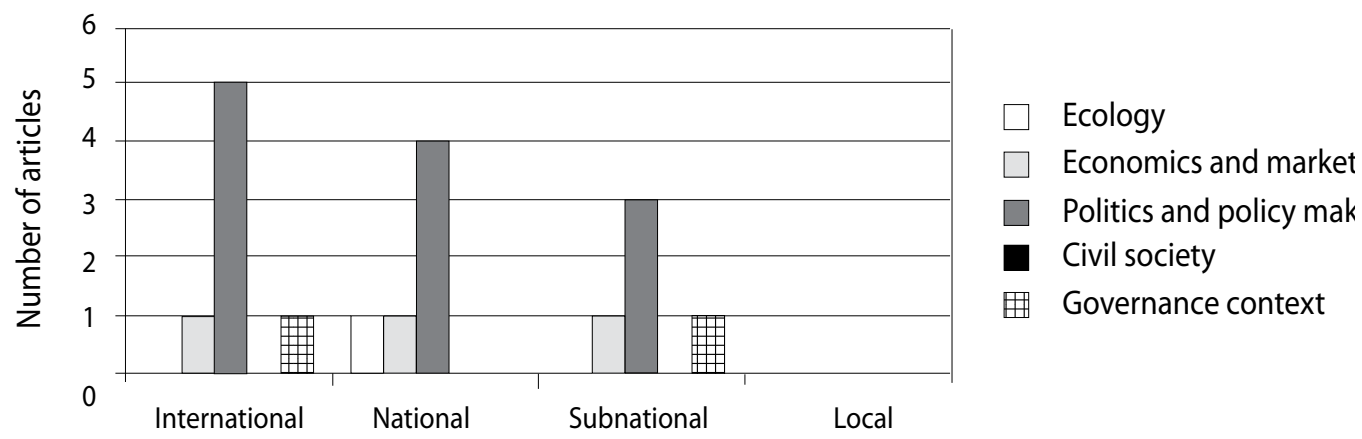

Figure 9. Metatopics by level

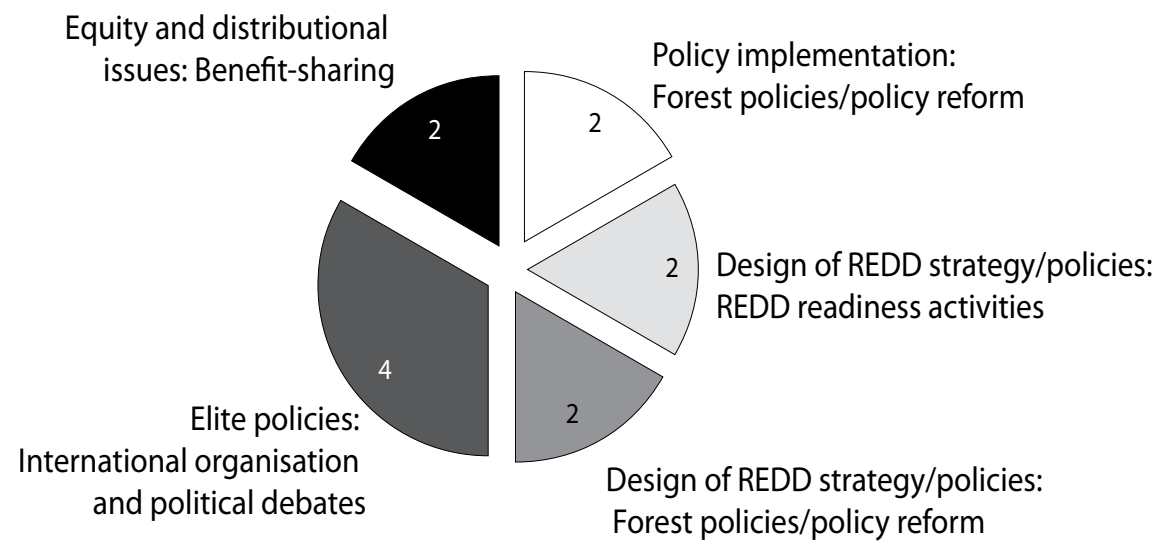

Figure 10. Subtopics of politics and policy making

Under the metatopic of 'politics and policy making', subtopics included: REDD+ policy design (4 articles); elite politics-meaning high-level political debates amongst national and international actors (4 articles); Policy implementationg: forest policies and policy reform ( 2 articles); and equity and distribution issues: benefit- sharing (2 articles) (Figure 10).

REDD + is viewed differently across the three newspapers. As the government voice, Nhân Dântypically discussed REDD+ in terms of new government policy and the need to implement it well at both national and local level. Tuổi Trẻ emphasised a sense of global connectedness and Vietnam's responsibility in the global effort to combat climate change. In spite of leaning towards the views of Nhân Dân, the dominant culture in Tuổi Trẻ is closer to Nông Nghiẹpp Việt Nam. Articles appearing in Tuổi Trẻ and Nông Nghiệp Viẹt Nam covered various
REDD+-related issues including: national policy design and implementation (enforcement of Decision 380/QD-TTg and Vietnam's efforts in implementing the UNREDD programme); ecological questions (Will REDD+ help save rich forests in Vietnam?); and political distributive issues (Who will benefit from REDD+?). Tuổi Trẻ emphasised the ethics of these issues, highlighting the importance of forests and the need to pay those who protect them.

\subsection{Key actors controlling REDD+ discourse}

Policy entrepreneurs (individuals or groups) are important in changing the direction and flow of policy implementation and politics (Crow 2010). The cultural politics of climate change in general and REDD in particular are dynamic and contested spaces battled out by various actors and through various 
frames and claims, these actors can influence climate science, governance and public understanding (Crow 2010).

REDD+ discourse in Vietnam is influenced by three principal groups of stakeholders. The first group are those who control and manage the country's mass media. The Ministry of Information and Communications is mandated with press management on the government's behalf. According to a key informant from Nhân Dân newspaper, editors must attend regular meeting with the Party's information committee to receive guidance and criticism. As with all issues, the extent to which REDD+ can be discussed is decided by these actors. According to an interviewee: 'The media is strongly regulated by the government so there are not many controversial debates in the media. Therefore, there are no supportive nor unsupportive voices concerning REDD in the media.'

The second group includes those who advocate and oppose REDD+. Within this group, three subgroups were identified (Table 5).

National-level state and bureaucratic actors make up $77 \%$ of advocates for REDD+ (12 out of 18 articles). Data analysis also showed that no nationallevel state and bureaucratic actors oppose REDD+ (Table 5). Frequently cited national bureaucrats include representatives from the government office (11\%), MARD (10\%) and provincial and commune people's committees in REDD+ pilot provinces (10\%). As discussed earlier, although 2 out of 18 articles were written by readers, these authors were retired government staff so they could be classified in this subgroup.

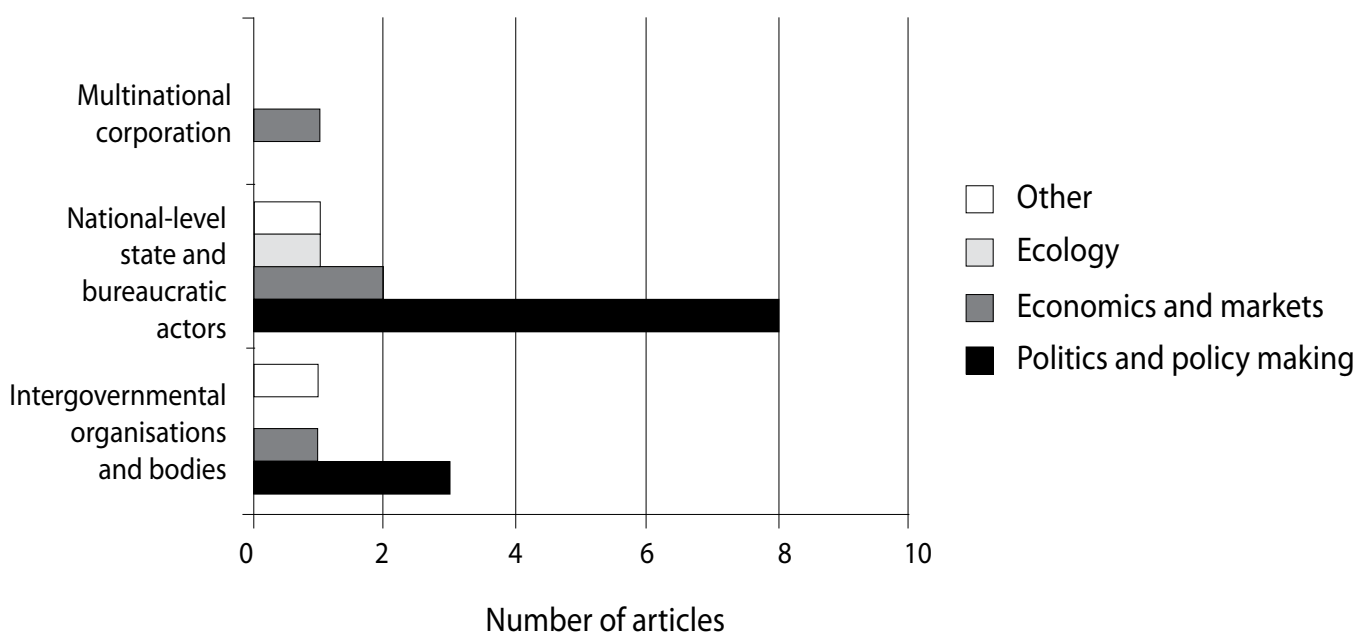

Figure 11. Actors and metatopics
Table 5. Advocates and adversaries of REDD+ in Vietnam

\begin{tabular}{lcc} 
& \multicolumn{2}{c}{ Number of articles } \\
Actors & Advocates & Adversaries \\
\hline $\begin{array}{l}\text { National-level state and } \\
\text { bureaucratic actors }\end{array}$ & 12 & 0 \\
\hline $\begin{array}{l}\text { Business associations } \\
\text { Intergovernmental } \\
\text { organisations and bodies }\end{array}$ & 0 & 1 \\
\hline
\end{tabular}

Intergovernmental organisations and bodies make up $33 \%$ of advocates for REDD+ (6 out of 18 articles). Frequently cited intergovernmental organisations and bodies include the Food and Agriculture Organization (FAO), the United Nations Development Programme (UNDP) and the United Nations Environment Programme (UNEP). No intergovernmental organisations and bodies opposed REDD+ (Table 5).

Business associations were the main adversaries of REDD+, including hydropower plants and the staterun company Electricity Vietnam (EVN). Business associations stated their concern to REDD+ in 5\% of articles. The enterprises cited were those who have to comply with Decision 380/QD-TTg in two pilot provinces: Da Nhim hydropower plant and Sai Gon water supply company.

The primary concern of national-level state and bureaucratic actors and intergovernmental organisations and bodies was 'politics and policy making' followed by 'economics and markets', while the primary concern of business associations was 'economics and markets' alone (Figure 11). 
National-level state and bureaucratic actors and intergovernmental organisations and bodies were discussed in connection with the design of REDD+ policies, funding of REDD+ processes, relations with donors, and design and implementation of financial mechanisms. Business associations were mentioned in the context of the impact of PES/REDD+ policy on their business interests. This group of actors asserted that since they already pay natural resources tax, additional payments for REDD+ will become a burden.

Since the Party plays the key role in influencing the media, the voice of NGOs was not represented in any of the articles searched. However, interviews with journalists added a third group of actors that play a critical role in shaping REDD+ debate and information in Vietnam. This group includes civil society organisations, such as the Vietnam Forum of Environmental Journalists (VFEJ); international media organisations, such as the BBC; and international NGOs working on sustainable development issues, such as Inwent. This suggests that journalists gain a lot of information informally through these actors. Although the government controls the media, the international press can still work with national institutes and civil society organisations to disseminate information about REDD+.

It is notable that the voice of national research institutions is also limited, which suggests that scientists have not been able to transfer their research findings into practice. This is partly explained by Dung (2008), who assets that journalists do not contact local people and scientists directly. Instead, they often get their stories from provincial departments of the Ministry of Natural Resources and Environment, Forest Inventory and Planning Institute and the National Institute of Meteorology, Hydrology and Environment.

Notable absentees from the list of actors include farmers and indigenous groups. One interviewee indicated that the VFEJ had interviewed some farmers and thus brought the voice of local people into the national debate; however, this is not mentioned in the relevant article.

\subsection{Future outlook for REDD+}

Although REDD+ is discussed at an international and national level in all selected articles, they mainly take a diagnostic approach (8 out of 18 articles) defining a problem related to REDD+, mostly deforestation. These articles also discussed the opportunities to conserve forests and generate revenues for the government and local communities protecting forests. According to most interviewees, forestry issues-particularly the alarming situation of forest loss-are widely discussed in newspapers in Vietnam. However, the interviewees also claimed that debates on environmental issues in general and on REDD+ in particular are sector oriented. Since MARD is the focal point for REDD+ in Vietnam, most articles see REDD+ as a forestry sector concern without acknowledging the complexity of issues and the need for a cross-sector approach to deal with it. Only $5 \%$ of articles took a prognostic approach, meaning they articulated a proposed solution to an issue or problem (Figure 12). This suggests that the debate on REDD+ in the media in Vietnam is yet to mature. Figure 12 illustrates the number of articles for each type of frame; the 'other' column is

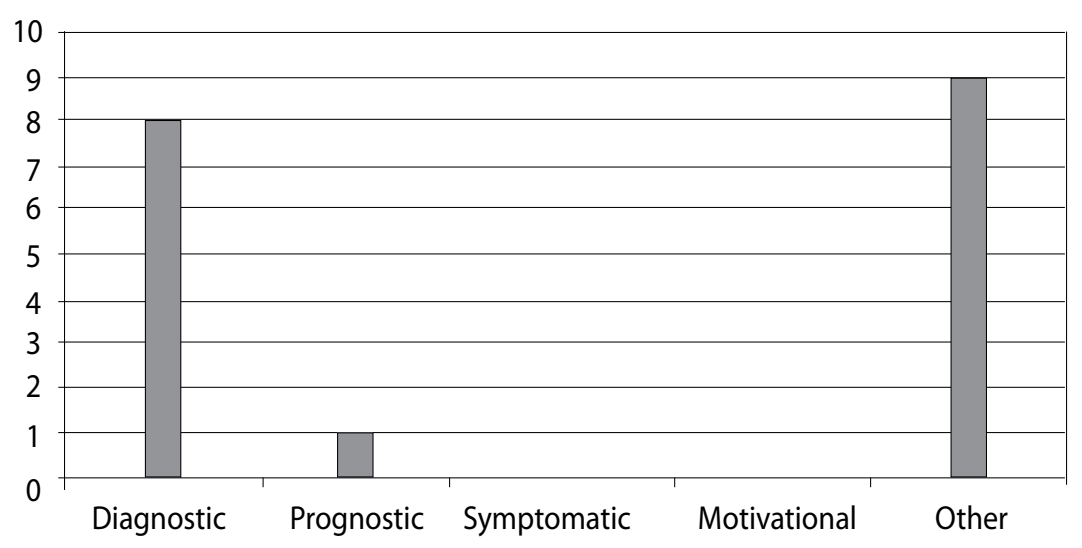

Figure 12. Types of frames 


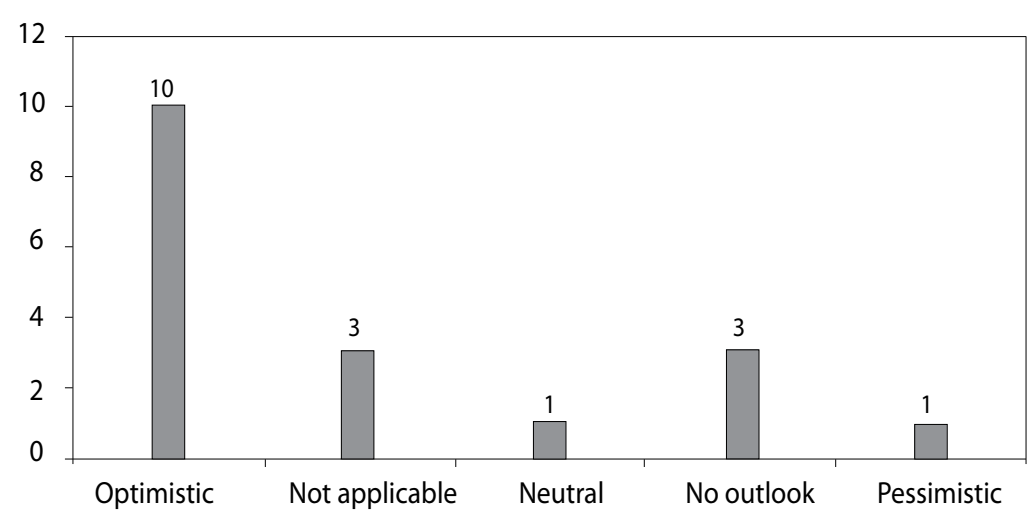

Figure 13. Outlook for REDD+ amongst commentators

particularly high because these articles either had just a short discussion of REDD+ or referred to REDD+ without discussing it.

Overall, between 2007 and 2010, 55\% of primary frame commentors (advocates and adversaries) offered an optimistic assessment of the future of REDD+ in Vietnam (Figure 13). Data analysis and interviews indicated that common reasons for their optimistic view towards REDD+ were a belief that REDD+ can improve the environment, reduce the burden of the forestry sector on the state, and improve local livelihoods. Amongst commentators, $5 \%$ had a pessimistic assessment of the future for REDD+ in Vietnam. These stances are thoroughly analysed in the Discussion section of this report.

Data analysis also shows that actors who were pessimistic about REDD+ were hydropower plants and environmental journalists. The representatives of hydropower plants expressed concern about Decision 380/QD-TTg and its impact on their profitability. The environmental journalist Khac Dung expressed his concern about the future of REDD+ and especially the implementation and enforcement of Decision 380/QD-TTg. In his article 'Payments for forest environmental services-who benefits?' in Nông Nghiẹpp Việt Nam Khac Dung wrote:

'A critical issue emerged is: will be any difference after the piloted programs of payments for forest environmental services for forest protectors? ... Furthermore, the Forest Protection and Development Fund has been established not only for those who protect and manage forests but will also be used for other purposes, such as financing programmes and projects related to forest protection and development. At the moment, it is difficult to assess the effectiveness of the programme and the fund.'
Another journalist, Kien Cuong analysed the issue in his article Payments for environmental forestry services-the responsibilities cannot be evaded' in Nông Nghiệp Việt Nam. He provided a neutral outlook, balancing problems with advantages of REDD+ schemes:

\footnotetext{
'Payments for forest environmental services are the right direction to take and will have a wide range of social, economic and environmental impacts. However, scaling up this policy throughout the country requires huge financial resources. Not all organisations and individuals who are using forest resources have a sense of forest protection and are willing to pay the fees. Therefore, right at the beginning of policy implementation, many stakeholders were late in paying the fees to the Forest Protection and Development Fund.... The challenge for payments for forest environmental services is awareness raising and it is really difficult.'
}

During the study period, an optimistic view of the future for REDD+ in Vietnam dominated the primary frame (Figure 14). However, it is interesting that since 2009 , slightly more diverse views on the future of REDD+ have been published. This shows that REDD+ has received increasing attention and was analysed at least in part from different perspectives.

When analysing particular future assessments of REDD+ against particular actor groups, national-level state and bureaucratic actors and intergovernmental organisations and bodies were overwhelmingly optimistic about REDD+. In contrast, business associations had a pessimistic assessment of REDD+ in the one article in which they were featured (Figure 15). Figure 15 also indicates that national-level bureaucrats dominate the primary frame. 


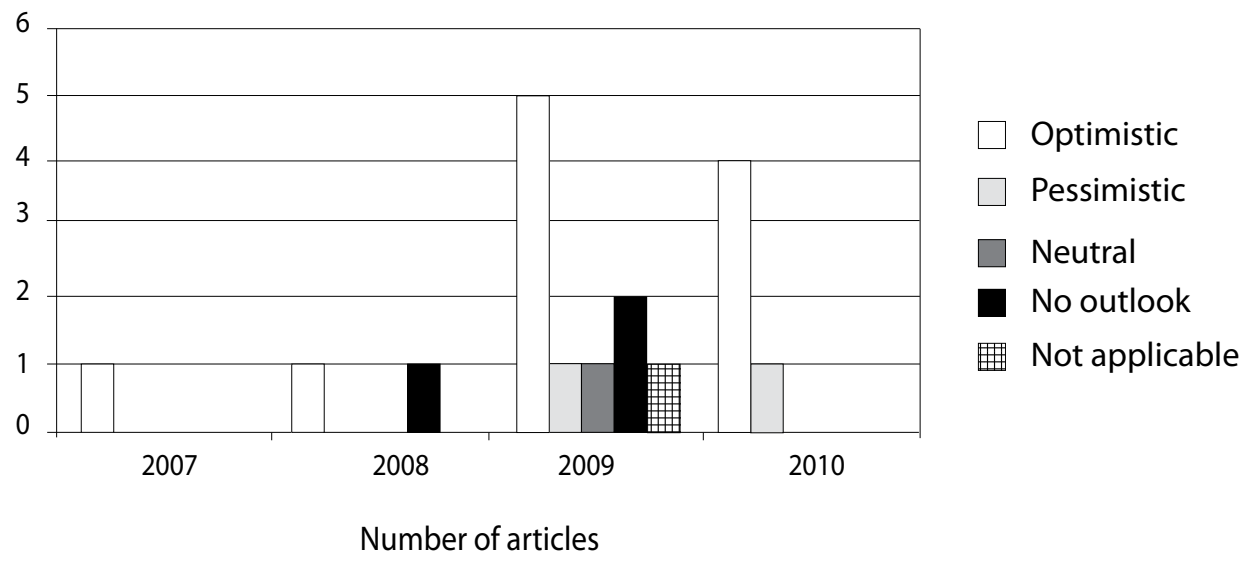

Figure 14. Outlook for REDD+ over time

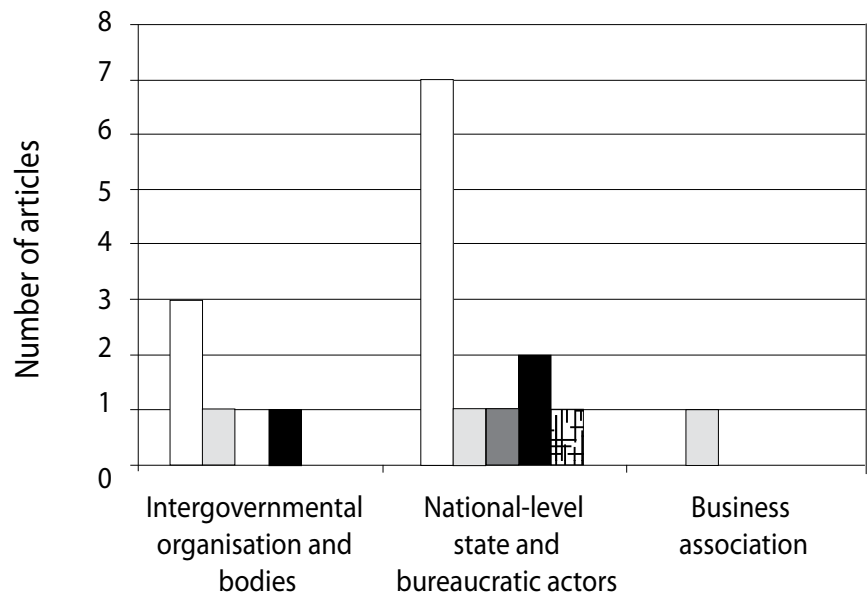

Optimistic

$\square$ Pessimistic

$\square$ Neutral

No outlook

Not applicable

Figure 15. Outlook for REDD+ by actor

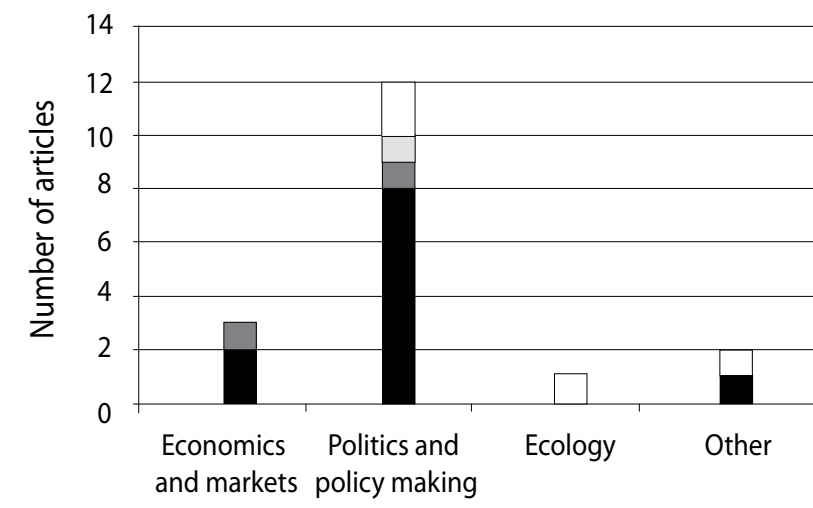

No outlook

$\square$ Neutral

Pessimistic

Optimistic

Figure 16. Assessment of the future of REDD+ and metatopics 


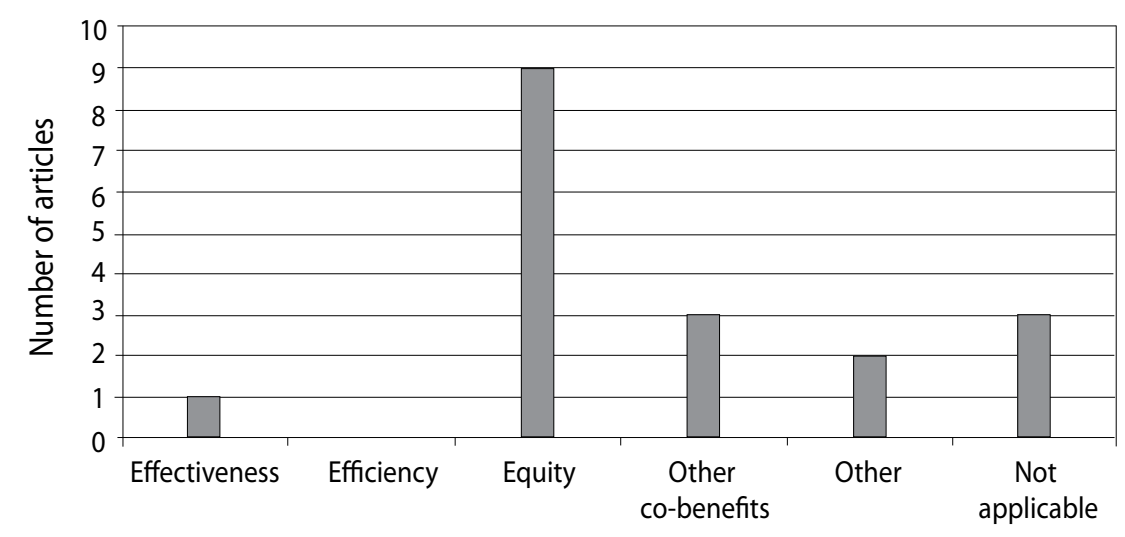

Figure 17. 3Es assessment

Data analysis also reveals interesting findings when assessments about the future of REDD+ are charted against particular metatopics (Figure 16). Actors framed within the context of 'politics and policy making' and 'economics and markets' offered a predominantly optimistic assessment of REDD+ (66\%) while actors framed within the context of 'ecology' did not express any view about the prospects for the future.

\subsection{Es assessment}

An analysis of the concerns of advocates and adversaries, in terms of effectiveness, efficiency and equity, indicated that equity and other co-benefits were the dominant concerns, evident in about $66 \%$ of articles (12 out of 18 articles) (Figure 17). Discussions of equity in these articles were framed around two major arguments: i) those who benefit should pay the costs; and ii) those who preserve forest should benefit from it. These were illustrated in several headlines including: 'Eat forests, pay for forests'; 'Those who benefit from forests will have to pay the fee'; 'Payments for environmental forestry services-the responsibilities cannot be evaded'; 'Payments for forest environmental services-who benefits?'; 'International Conference on Climate Change in Bali-Protecting forests will be rewarded billions of US\$'; 'Hydropower plants pay for forest protection'.

Of articles framed around equity issues, 3 out of 9 addressed the international level while the remaining addressed the national and subnational level.
The three international-level articles all argued that developed countries should pay developing countries to protect and preserve forests. Disagreement between developing countries and developed countries on this principle was also mentioned. For example, in the article 'International Conference on Climate Change in Bali-Protecting forests will be rewarded billions of US\$' (2007) Thanh Tuan wrote:

'... REDD can help developing countries to earn billions of US\$ by simply protecting forests.... This is an appropriate incentive for developing countries to pay more attention to reforestation and forest protection. Countries that are currently opposing this mechanism are the US, and recently developed countries such as China and India.'

In the article 'Prime Minister Nguyen Tan Dung: There is a need for collaboration amongst all countries to combat climate change' (2009) the author quoted the Prime Minister:
'Developed countries and those with high emission rates have to support countries that are seriously impacted by climate change, particularly rising sea levels, including Vietnam, by providing preferential mechanisms and financial support, technology transfer, and capacity building to enhance their climate change coping strategies.'

At the national level, these articles were framed around equity issues, highlighting the responsibilities of hydropower plants, water supply companies and tourist companies to pay upland people who protect the forests. Kien Cuong, in his article 'Payments for environmental forestry services-the responsibilities cannot be evaded' quoted the Deputy Prime Minister Nguyen Sinh Hung: 'Organisations and individuals 


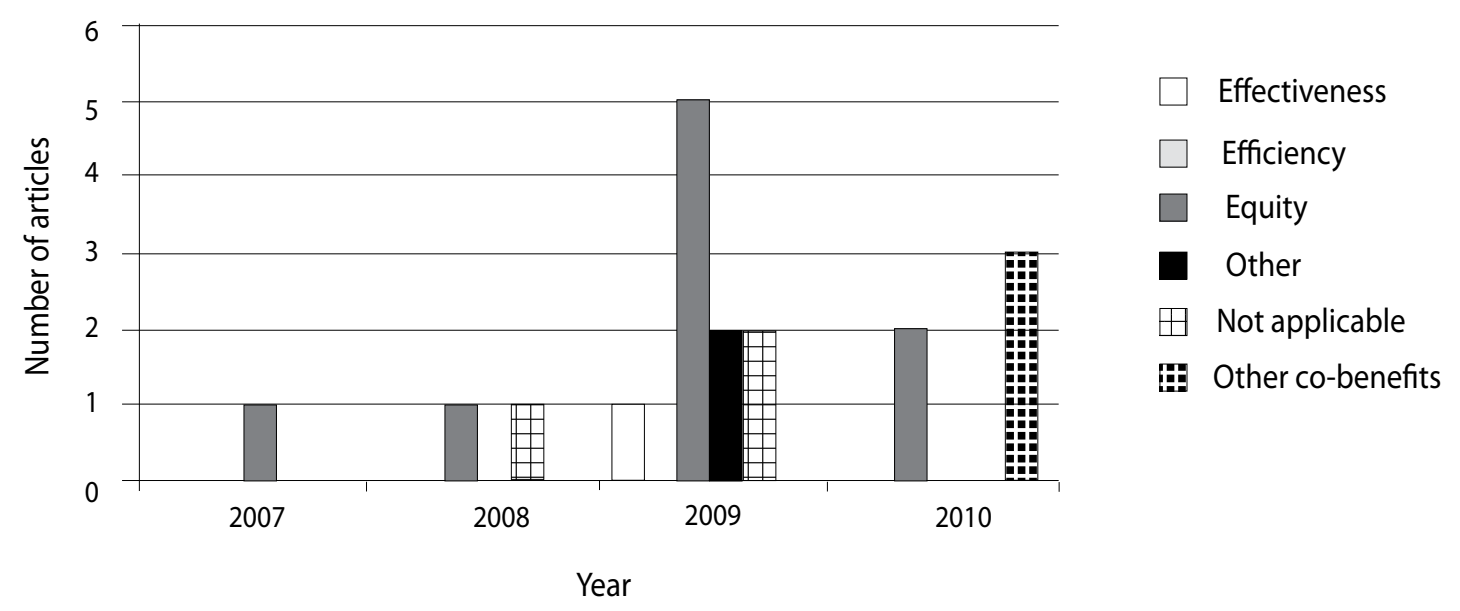

Figure 18. 3Es coverage over time

who use and benefit from forest resources should not ignore their responsibility to pay for them.'

The equity frame also included articles that discussed who will actually benefit from REDD+ payments. In the article 'Payments for forest environmental services-who benefits?' published in Nhân Dân newspaper in 2009, Khac Dung posed the question: 'The critical issue is: Who will benefit from piloting payment for environmental services?' To address this question, the journalist looked at the PES scheme in Lam Dong province and discussed the additional income that local communities received as a result of Decision 380/QD-TTg.

Of the 18 articles, 3 were framed around other co-benefits of REDD+, in particular biodiversity conservation (1 article) and the potential for REDD+ to improve the livelihoods of people who live around and are dependent on forests ( 2 articles). Amongst these, 1 article referred to the international context, while the other 2 discussed government expectations for the positive impact on local income of Decision 380/QD-TTg.

There were no articles framed around the issue of efficiency in the three selected newspapers and only 1 article out of 18 was framed around effectiveness. The only article that referred to effectiveness was 'Forum on Forest Carbon Partnership', which appeared in Nông Nghiệp Việt Nam in 2009 and was written by Truong Giang. In this article, the author wrote: 'Mr Andrew Speedy, Asian Pacific representative of FAO asserted that, REDD is a major carbon financing mechanism. This mechanism plays a critical role in preventing illegal logging and illegal timber trading in the region.'

Although none of the interviewees provided an explanation as to why there was no article discussing efficiency, studies conducted by Pham et al. (2009) and Pham et al. (2010) offered an explanation: most of the establishing, implementing and transaction costs for PES and REDD+ were not considered by the environmental service sellers, providers and intermediaries, because their primary goal was to pilot these schemes. Most transaction costs were covered by the intermediaries themselves because they were allocated funding from donors and buyers to cover such costs.

The limited number of articles discussing effectiveness could be explained by the fact that both PES and REDD+ are still in their infancy, globally and in Vietnam in particular, and evidence on its effectiveness is limited.

Equity has been at the centre of the debate about REDD+ in the media in Vietnam since 2007, while effectiveness only gained attention in 2009 and other co-benefits in 2010 (Figure 18). The increase in the number of articles and range of REDD+-related issues covered overtime shows that policy makers and the media have paid increasing attention to $\mathrm{REDD}+$ and have explored the issues from a variety of perspectives. 


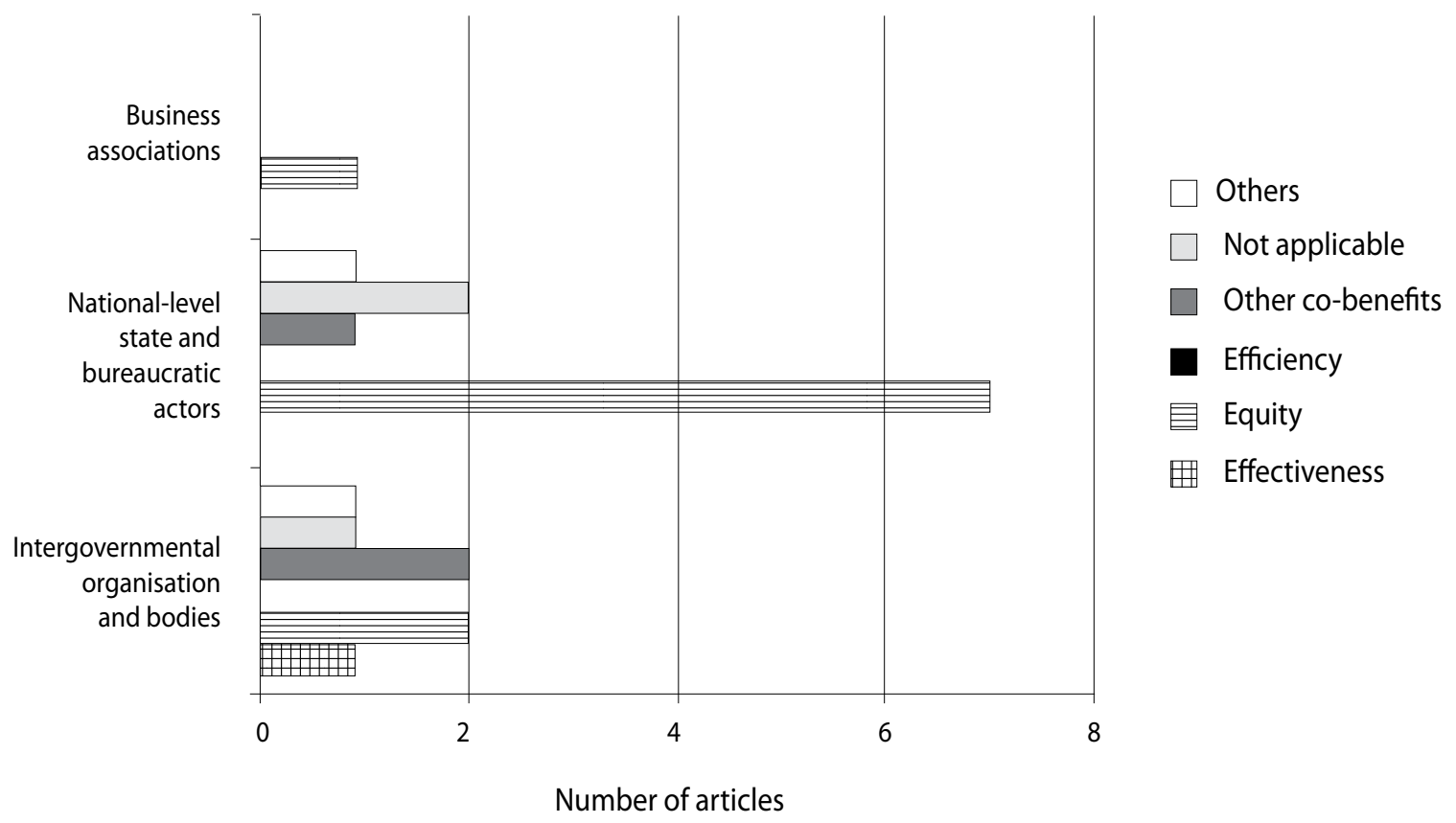

Figure 19. Actors and the 3Es

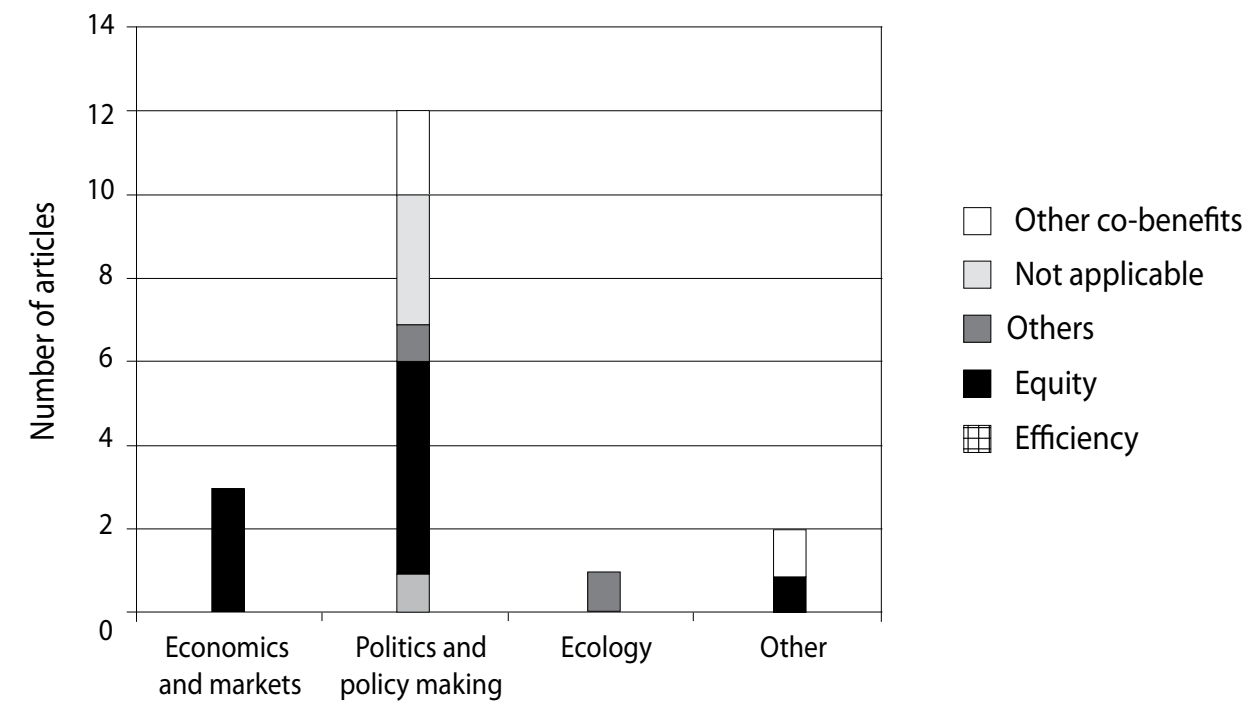

Figure 20. Metatopics and the 3Es

International organisations and bodies such as the FAO and UNDP, and national-level state and bureaucratic actors such as MARD and the Government Office were concerned primarily with issues of equity and other co-benefits, while effectiveness was only a concern for international organisations (FAO) within the primary frame (Figure 19). Business associations such as EVN were concerned primarily with issues of equity, since they had already paid natural resource use tax.

In terms of how the 3Es relate to topics, 'politics and policy making' is assessed in terms of equity, effectiveness and other co-benefits, without reference to efficiency. 'Economics and markets' is assessed in terms of equity without considering effectiveness or efficiency (Figure 20). 
It is interesting that ecology was not viewed through the lens of the 3Es although it could play a critical role in shaping the design and implementation of REDD+. Ecology was discussed in the relation to the current classification of forests in Vietnam. According to the article 'Poor forests' written by Nguyen Chi Thanh and published in Tuoi Tre newspaper, 'poor forests' are defined in Vietnam as forests that have been over exploited and no longer provide timber. With this definition, people often perceived 'poor forest' as of no value. However, the author claimed that these 'poor forests' are still able to provide environmental services such as increasing soil coverage, retaining groundwater, reducing erosion, regulating water flow and reducing storms and floods. With the approval of Decision 380/QDTTg, the author argued that these environmental services could be quantified and paid for. Therefore, the government should change the classification of 'poor forest' to 'restoration forest' so that this forest can be protected. 


\section{Discussions and recommendations}

\subsection{REDD+ media coverage in Vietnam}

As the previous sections have shown, REDD+ coverage in Vietnam is still in its infancy. However, the rapid increase in the number of articles on REDD+ and the range of issues covered overtime shows that REDD+ has received increasing attention from policy makers, readers and the media. This is due to global developments, including the Conference of Parties in 2007 (COP13) and the approval of Decision 380/QD-TTg and the United Nations Collaborative Programme on Reducing Emissions from Deforestation and Forest Degradation in Developing Countries (UN-REDD) UN-REDD in 2008. This shows that the media has effectively reflected the REDD+ policy process and the importance of REDD+ issues amongst state actors in Vietnam. The fact that most actors offered an optimistic assessment of the future of REDD+ also shows a strong belief on the part of government and other stakeholders in the importance of REDD+ to the national economy, particularly the forestry sector. However, the fact that REDD+ coverage is more limited than coverage of other climate change issues, shows that REDD+ is not at the centre of the national debate on climate change, which is focused on water issues, particularly rising sea levels, and efficient energy use.

As stated earlier, the objective of this study was to assess whether the media can influence policy outcomes. Data analysis indicated that the media is linked to the policy cycle (policy formulation, implementation and evaluation) but has no influence on policy outcomes for two major reasons. First, the main purpose of media coverage in Vietnam is to help the government enforce its policy. The interviewees suggested that media impact on policy outcomes is limited as a result. Secondly, REDD+ is still at the pilot stage and limited understanding of REDD+ amongst journalists, as well as limited evidence on REDD+ policy impacts impede journalists in communicating the implications of policy.
Furthermore, analysis of the selected articles shows that while the media discusses REDD+ in terms of equity (e.g. benefit sharing mechanisms, rights and responsibilities of actors) there is no discussion of efficiency. Since most payment for environmental services (PES) and REDD+ schemes in Vietnam are pilot programmes, the government and donors are not concerned about cost related to REDD+. Further studies and analysis should be conducted on this topic to prepare for national implementation of Decision 380/QD-TTg, given that transaction costs for PES schemes were found to be very high (Pham et al. 2009, Pham et al. 2010).

Equity issues are the primary focus of both policy and media coverage. Many stakeholders are concerned about whether an appropriate benefit-sharing mechanism can be developed and implemented, since there is a lack of supportive policies, mechanisms and tested guidelines to achieve an effective, transparent and practical payment system for individual households (Hoang et al. 2010). It is interesting that coverage of equity issues has both international dimensions (payments from developed to developing countries) and national dimensions (payments to the poor). This shows the position of Vietnam in the international REDD+ debate and its effort to ensure an equitable benefit sharing mechanism for its citizens. However, as Pham et al. (2008) highlighted, the pro-poor impact of REDD+ and PES might be limited due to high transaction costs, a low level of payments and overlapping functions amongst state actors. The limited voice of the poor in media coverage and REDD+ policy formulation (Hoang et al. 2010) also shows the gap between policy objectives and implementation on the ground.

Furthermore, van Noordwijk et al. (2007) argued that PES schemes are workable if they are: i) realistic (based on recognisable cause-effects pathways involved in the production of environmental services, and with benefits gained by both sellers and buyers being tangible and sustainable); ii) voluntary (engagement of environmental service providers and sellers is based on free choice rather than obligatory 
through regulation); iii) conditional (environmental service provision is only rewarded if provided); and iv) pro-poor (equitable impacts on all actors and PES design is positively biased towards poor stakeholders). Hoang et al. (2008) claimed that government control means that 'voluntary' will be the most difficult of these criteria to achieve in Vietnam. Concerns about PES not being voluntary were raised in the media as a major obstacle for implementation, since payments will not be sustained if they are not based on willingness on the part of environmental services users. This supports the analysis of Villamor $e t a l$. (2007), which calls for further studies and analysis exploring the perceptions and willingness to pay of environmental service buyers.

The REDD+ debate takes place in the context of impacts of climate change in Vietnam and is integrated with discussions about adaptation and mitigation. This is a major difference from the discourse in the West. This is also reflected in the policies adopted. PES is seen as an essential element of REDD+ due to the fact that equity issues are a priority (MARD and UN-REDD 2010).

\subsection{The limits of the REDD+ media discourse in Vietnam}

The media is expected to be a useful channel for all stakeholders in society to express their perceptions on particular issues. However, the way climate change is reported depends on the economic, cultural and sociopolitical characteristics of a country (Boykoff 2007, Carvalho 2007, Boykoff and Mansfield 2008, Anderson 2009). As the previous sections have shown, the mass media in Vietnam is a means of propaganda for government policies, so media coverage represents the Party's perceptions and assessment of REDD+. This also partly explains why most REDD+ discussions in the selected newspapers were framed around politics and policy making and did not address a wider range of issues and debates. While the role and impact of the media in Vietnam is limited compared with Western media (Tran 2005, Eek and Ellström 2007, McKinley 2007), the public can still be optimistic about the future impact of the media on the REDD+ arena, since the media has been able to 'get out of the box' and successfully target more sensitive issues such as corruption (McKinley 2007).
Globally, there is considerable competition amongst (and between) scientists, industry, policy makers and nongovernmental organisations (NGOs), each of whom is likely to be actively seeking to establish their particular perspectives on the issues as the one to be adopted (Anderson 2009). The fact that other stakeholders, who might have different views on REDD+, have limited room to express their views also means that the media in Vietnam has not been able to represent all social actors who might have an influence on REDD+. It is suggested that a REDD+ forum should be established so that these actors can share their information and suggestions towards REDD+ implementation.

Moreover, the media has not been able to inform the public on critical debates related to REDD+ that are discussed widely in the international media and academic papers, such as the issues of regional and national leakage (EIA and Telapak 2008, Meyfroidt and Lambin 2009, Forest Trends 2010, Hoang et al. 2010, MARD and UN-REDD 2010UNREDD), involvement of indigenous people (Hoang et al. 2010), insecure tenure (Lee and Mahanty 2009, Pham et al. 2008) and technical issues such as carbon measurement and difficulties in defining emission baselines (Nguyen et al. 2010). Since the government sees PES and REDD+ through the lens of tax and fees (Pham et al. 2010) the media only discussed these issues without looking at other forms of REDD+. As this study reveals, the media discourse focuses on policy and related economic issues (such as markets, hydropower development, taxes and fees etc.) not on environmental aspects. Furthermore, analysis of the data collected also suggests that stakeholders are often optimistic about REDD+, while potentially negative impacts are overlooked or poorly-researched. Capacity building and enhanced understanding of REDD+ should be facilitated so that the public has access to a comprehensive picture of the REDD+ debate.

\subsection{Who is to blame for the limited coverage of REDD+?}

Since 2007, climate change and REDD+ have been treated with greater urgency as the topic has risen up the political agenda, and journalists have increasingly discussed REDD+ in print. Despite this improvement in frequency and quantity of coverage, 
the quality of media reports continues to concern the public and scientists (Boykoff and Boykoff 2007). Two common explanations for poor reporting on climate change are capacity constraints (Shanahan 2007, Boykoff and Mansfield 2008, Anderson 2009) and political factors defining the content of reports.

Borton (2005), Shanahan (2007) and Boykoff and Mansfield (2008) highlighted the fact that journalists and editors in developing countries often do not have a science background or receive training in climate-change reporting, so technical errors appear in published articles. In poorer countries such as Vietnam, few reporters are well trained, connected and resourced. As discussed earlier, limited understanding of REDD+ is seen as a major constraint for journalists. REDD+ issues are technical issues, which are becoming more popular discussion topics, so the barriers might be higher.

Fahn (2008) pointed out that poor reporting on climate change and REDD+ is not because of lack of commitment from journalists on covering the issues, but rather the inordinate number of obstacles they face. Specifically, Boykoff and Mansfield (2008) pointed to constraints deriving from political and economic pressures and limited specialist training and understanding. Media coverage can also be influenced by professional cultures and distinctive ideological standpoints (Carvalho and Burgess 2005). As Anderson (2009) suggests, the organisational and institutional routines and working regulations of newspapers determine to what extent the issues can be covered. Reporters cannot be impervious to political pressure and introduce all sides of the issue from an unbiased perspective (Anderson 2009). Moreover, since the government controls the media in Vietnam, it tends to be the 'primary definer' of key issues (Anderson 2009).

While journalists' lack of knowledge of the issues is often blamed as the primary reason for poor and biased reporting of REDD+, Shanahan (2007) argues: 'The media's job is not to change the world. It is up to society to turn bad news into good.' Those supplying the media with information-scientists, politicians and NGOs_-share some of the blame. One of the reasons that journalists in Vietnam have a poor understanding of REDD+ is a lack of knowledge transfer from scientists to the media and the general public on the issue. Science is often asked to 'come out to the street' and to be the basis of political decisions (Beck 1992). Policy makers often expect scientists to provide answers to problems that are debated in the media and other public arenas, and make a variety of public uses of science to legitimise action or inaction (Carvalho 2007). However, scientists have long struggled to step outside their circle and this means many resist telling their stories simply and without jargon-a turn-off for the public (Shanahan 2007). Too often scientific studies and results are obscured by technical language and jargon, which does not translate smoothly into the crisp, unequivocal commentary that is valued in the press (Boykoff and Boykoff 2007). This is also the case in Vietnam. Most REDD+ research findings are too technical to be accessible to journalists and the public, leaving an urgent need for dissemination of REDD+ findings in general language. From journalists' and readers' points of view, more scientific studies on the impacts of climate change on people's daily lives are needed, communicating stories they can connect with. Furthermore, research institutes in developing countries are often without a press office, and their scientists can be reluctant to talk to the media (Fahn 2008). National research institutes need to participate more actively in the debate to enhance the limited voice of scientists in the media.

\subsection{Influence of the private sector}

While private sector reactions to climate change are still small relative to what powerful scientific, economic and moral arguments demand (Shanahan 2007), media reporting of climate change has become increasingly affected by industry interests (Shanahan 2007, Anderson 2009). Pham et al. (2008) analysed Decision 380/QD-TTg and claimed that although water and hydropower companies are targeted as environmental service buyers in this policy, the government is reluctant to apply the regulations to these groups as they contribute significant amounts to the government budget through tax, and increased charges and fees would create problems. Moreover, increased water and electricity prices might lead to increased prices for many products, which will affect the national economy. Although the private sector has a limited voice, and no visible impact of this actor was illustrated in the articles searched, it is expected that they will play a critical role in determining the success or failure of REDD+ implementation in Vietnam. Again, understanding 
their perceptions and willingness to pay is essential for future implementation of REDD+.

\subsection{Where are the poor?}

Shanahan (2007) asserted that the key challenges for climate change coverage include making stories more relevant to audiences, raising the profile of adaptation and the perspectives of the poor, and reporting on ways to address climate change that bring additional benefits. Shanahan (2007) and Fahn (2008) further expressed the concern that no information was given on any media about how the poor would be affected by REDD+ at the global level. An Oxfam study (2009) also highlighted that the communities most vulnerable to climate change need financial support to adapt, but this aspect of climate change is underreported. As a result, the voices of the vulnerable are rarely heard by those in power (Shanahan 2007). This is supported by our analysis of articles and interviews, which show that the current debate on REDD+ is dominated by government and international NGOs, while the voices of environmental service sellers, ethnic groups, the poor and women were absent. REDD+ must target the most vulnerable and ensure they have a voice in planning and decision-making processes to address climate change.

The current discussion of REDD+ is biased toward the buyers and government policies without considering vulnerable groups. To enhance the voice of vulnerable groups, it is important to have trusted and accountable intermediaries to represent them (Pham et al. 2010), yet few stakeholders bring their interests into the policy making process. Potential intermediaries in Vietnam include international and national NGOs, local organisations (the Farmer's Association and the Women's Union) and local actors (e.g. heads of villages).

\subsection{The way forward}

Improving coverage of REDD+ will become crucial as the area becomes increasingly challenging and complex to report on. Media professionals will need to find new ways to sustain readers' attention over time, particularly when other 'competing' issues such as the economy take precedence (Anderson 2009). In order to achieve this, several recommendations are made.
Firstly, journalist's training needs to be enhanced. The Ministry of Information and Communications issued a call to increase the quality of its media, invest in new media technologies, and improve the training of its reporters (Borton 2005). Interviewees also suggested that journalists should receive more environmental training, particularly on REDD+. The question is, however: Does providing more training to journalists increase REDD+ coverage and the quality of reporting? According to most interviewees, the answer depends on how the training is organised and who is targeted. Interviewees shared the conclusions of Fahn (2008), who asserted that it is difficult for journalists in developing countries to access experts, peer-reviewed journals and other information. Thus, interviewees asserted that training should be organised in the form of seminars, where environmental journalists can first study and then debate the issue. More importantly, they need to go into the field to study and write up their observations after this training. Opportunities for peer review would also enrich the skills of journalists. This training requires funding, but more importantly attendance of scientists who have expertise on REDD+ to act either as trainers or guest speakers. With a little time and training, nonscientific journalists should be able to cover climate change well (Shanahan 2007).

While additional training for national journalists is essential, journalists who have already been trained by the international institute such as Inwent should act as 'seeds' to help support colleagues, and should be encouraged to continue following REDD+ issues. Unfortunately, journalists at the national radio did not report on REDD+ even after receiving training from international organisations on the topic. This study also supports Anderson's (2009) assertion that REDD+ has to compete with other 'hot' topics in order to sell newspapers, and shares similar findings with Boykoff (2007) and Shanahan (2007) that editorial preferences and publisher pressures can affect news reporting. Interviewees stated that if REDD+ advocates want to encourage newspaper coverage, they need to provide training for editors and stimulate their interested in REDD+. Once they understand what REDD+ means and its importance, they will direct journalists to cover the topic.

Secondly, research involving in-depth interviews with editors and reporters would provide important 
insights into the factors impeding or enhancing climate change coverage. Such studies would provide a greater understanding of competition to control the issue and the behind-the-scenes factors influencing patterns of reporting (Anderson 2009). Also, few studies have included interviews with scientists about their media relations (e.g. Boykoff 2007). This calls for further research on how scientists can better connect with the media.

Thirdly, expertise should be expanded beyond that related to science, and other forms of expertise (e.g. lay knowledge, counterexpertise from civil society actors) should be brought into the governance process (Giessen and Böcher 2009). Ideally, policy making should be based on solid science and "accountable expertise" as this ensures their effectiveness and legitimacy. Knowledge sharing through formal channels such as technical workshops and conferences is only one amongst many effective channels. As was shown in the previous section, in addition to existing formal channels such as government officials and government agencies, informal channels such as civil society groups, international NGOs and international media outlets also contribute funds and technical expertise to support journalists approaching REDD+. These networks should be strengthened and a forum should be established to enhance information and knowledge sharing between actors.

International NGOs and civil society groups are invited informally to participate in climate change meetings. Future structures should consider a formal role for these organisations, which have substantial technical capacity and experience of working with vulnerable communities. These organisations can provide valuable input into REDD+ design, as well as on the ground implementation. REDD+ networks are already in place, and if strengthened, could provide an efficient link to government structures. The government should also consider ways of coimplementing projects or providing funding to these organisations to work on REDD+ issues. The government, civil society organisations and NGOs should work together to establish ways in which accountability to vulnerable groups can be improved. 


\section{Conclusions}

REDD + coverage in Vietnam has increased rapidly despite a late start compared with international media. This study found that coverage on REDD+ started in 2007 and increased thanks to the launch of numerous REDD+ related policies and programmes. The number of articles and breadth of discussion about REDD+ in the media shows increasing attention and support from the government towards REDD+. However, REDD+ receives much less coverage than some other climate change issues mainly because i) the major focus of climate change concerns in Vietnam is rising sea levels not REDD+, ii) journalists have a limited understanding of REDD+, and iii) the voices of scientists, the private sector and civil society organisations are limited in the policy making process.

The study also shows that the media in Vietnam is controlled by the government, so media content on REDD + is mainly used to disseminate Party policy. Thus, coverage on REDD+ has been mainly framed around the enforcement and implementation of the national REDD+ programme and REDD+ policies, as well as associated effectiveness and equity issues. Efficiency issues have not been widely discussed in the media because the government and donors are willing to cover the related costs of REDD+. Intergovernmental organisations and government agencies were identified as the key actors discussing REDD +. The perspectives of business enterprises were raised, but the voices of scientists, international nongovernmental organisations (NGOs), civil society and marginalised groups were absent. Furthermore, the findings highlight that the media has not covered controversial and critical issues related to REDD+ that have been raised often in the international media, such as leakage and involvement of indigenous groups.

Although the media is controlled by the government, this study shows the potential impact of the media on the REDD+ arena since it has been able to tackle some sensitive issues, such as the degree to which participation in REDD+ is voluntary. Moreover, the study suggests that journalists should not be blamed for limited REDD+ coverage as government, scientists, civil society and NGOs also share some responsibility. However, the fact that most stakeholders are optimistic about the future of REDD+, without considering the potential negative impacts on local livelihoods, calls for better dissemination of research results to the media and public. The findings of this study also support other international and national research which calls for further study on the perception and willingness of environmental service buyers and the impact of REDD+ on the poor. Further training for journalists on REDD+ and better coordination and knowledge sharing amongst stakeholders are essential in improving current media coverage and facilitating REDD+ implementation in Vietnam. 


\section{References}

Anderson, A. 2006 Media and risk. In: Walklate, S. and Mythen, G. (eds) Beyond the risk society, 114-131. Open University/McGraw Hill, Milton Keynes, UK.

Anderson, A. 2009 Media, politics and climate change: towards a new research agenda. Sociology Compass 3(2): 166-182.

Angelsen, A. 2009 Introduction. In: Angelsen, A. (ed.) Realising REDD+: national strategy and policy options. CIFOR, Bogor, Indonesia.

Angelsen, A. (ed.) 2008 Moving ahead with REDD: issues, options and implications. CIFOR, Bogor, Indonesia.

Asia New Zealand Foundation 2010 Vietnam media environment. http://www.asianz.org.nz/our-work/ media/covering-asia/vietnam (7 Feb 2011).

Baron, J. 2006 Thinking about global warming. Climatic Change 77: 137-150.

Beck, U. 1992 Risk society: towards a new modernity. SAGE, London.

Bendix, J. and Liebler, M.C. 1991 Amazonia: perspectives in US news media. Professional Geographer, http://www.informaworld.com/ smpp/title\%7Edb=all\%7Econtent $=$ t788352615 $\% 7 \mathrm{Etab}=$ issueslist $\% 7 \mathrm{Ebranches}=43-\mathrm{v} 4343(4)$ : 474-485.

Blog.modernmechanix.com 2006. Growing blanket of carbon dioxide raises earths temperature Available at: http://blog.modernmechanix.com/ 2006/03/ 21/ growing-blanket-of-carbon-dioxideraises-earths-temperature/.

Borton, J. 2005 Vietnam makes a start on reform. Asia Times Online http://www.atimes.com/ atimes/Southeast_Asia/GA12Ae03.html (7 Feb. 2011).

Boykoff, M.T. 2007 From convergence to contention: United States mass media representations of anthropogenic climate change science. Transactions of the Institute of British Geographers NS 32: 477-489.

Boykoff, M. 2008 The cultural politics of climate change discourse in UK tabloids. Political Geography, vol. 27, Elsevier.
Boykoff, T.M. and Boykoff, M.J. 2007 Climate change and journalistic norms: a case-study of US mass-media coverage. Geoforum 38: 1190-1204.

Boykoff, T.M. and Mansfield, M. 2008 Ye olde hot aire: reporting on human contributions to climate change in the UK tabloid press. Environmental Research Letters.

Carvalho, A. 2007 Ideological cultures and media discourses on scientific climate change. Media, Culture and Society 17: 49-64.

Carvalho, A. and Burgess, J. 2005 Cultural circuits of climate change in the UK broadsheet newspapers, 1985-2003. Risk Analysis 25: 1457-70.

CIFOR 2010a. GCS-REDD: Global comparative study on REDD. http://forestsclimatechange.org/ survey.html (7 Feb. 2011).

CIFOR 2010b. Overview of the research design of component 1. CIFOR, Bogor, Indonesia.

Clark, H. 2009 Heeding climate change warnings. http://ipsnews.net/ news.asp?idnews $=44046$

Cronin, T. and Santoso, L. 2010 REDD+ politics in the media: a case study from Indonesia. Working Paper 49. CIFOR, Bogor, Indonesia.

Crow, A.D. 2010 Local media and experts: sources of environmental policy initiation? The Policy Studies Journal 38(1).

Dittmer, J. 2005 Captain America’s empire: reflections on identity, popular culture, and post-9/11 geopolitics, Annals of the Association of American Geographers 95 (3) (2005), pp. 626-643.

Dung, N.T. 2009 Vietnam responds to climate change. Available at: www.presscenter.org.vn/en/ componentloption,com_ionfiles/.../fileid,50/

Dung, P.H. 2008. Climate change coverage by the Vietnamese media, Earth Journalism Network http://www.earthjournalism.org.

Dung, P.H. 2010. Climate change coverage by the Vietnamese media: four-year trend 20062009, Institute for Health Environment and Development, Vietnam. 
Eek, C. and Ellström, E. 2007 An actor in the Vietnamese media landscape: a case study of the online newspaper VnExpress. School of Education and Communication, Jönköping, Sweden.

EIA and TelaPak. 2008. Borderlines: Vietnam's booming furniture industry and timber smuggling in the Mekong region. TelaPak, Bogor, Indonesia.

Entman, R.M. 1993 Framing: towards clarification of a fractured paradigm. Journal of Communication 43: 51-8.

Fahn, J. 2008 Poor countries' media must tackle climate change. Available at: http://www. internews.org/articles/2008/20080808_scidev_ fahn.shtm.

Forest Trends 2010 Timber markets and trade between Laos and Vietnam: a commodity chain analysis of Vietnamese-driver timber flows. Washington, DC.

Harbinson, R., Richard, M. and Chawla, A. 2006 Whatever the weather: media attitudes to reporting climate change. Panos Institute, London.

Hoang, M.H., vạn Noordwijk, M. and Pham, T.T. (eds) 2008 Payment for environmental services in Vietnam-Lessons and experiences in Vietnam. World Agroforestry Centre in Vietnam, Hanoi, Vietnam.

Hoang, M.H., Do, T.H., van Noordwijk, M., Pham, T.T., Palm, M., To, X.P., Doan, D., Nguyen, T.X. and Hoang, T.V.A. 2010 An assessment of opportunities for reducing emissions from all land uses: Vietnam preparing for REDD. Final national report. ASB Partnership for the Tropical Forest Margins, Nairobi, Kenya.

Institute of Strategy and Policy on Natural Resources and Environment of Vietnam 2009 Vietnam assessment report on climate change. Ministry of Natural Resources and Environment, Hanoi, Vietnam.

4 International media. Tuoi Tre Webranking. Available at: http:// www. 4imn. com/ reviews/ 18127.htm.

Lee, E. and Mahanty, S. 2009 Payments for environmental services and poverty reduction: risks and opportunities. RECOFTC Issues Paper. Center for Forests and People, Bangkok, Thailand.

Mansfield, M. 2007 Workshop summary, Carbonundrums: making sense of climate change reporting around the world. http://www.eci. ox.ac.uk/news/events/070727-carbonundrum/ summary.pdf (7 Feb 2011).
MARD and UN-REDD 2010 Design of a REDDcompliant benefit distribution system for Vietnam. United Nations Collaborative Programme on Reducing Emissions from Deforestation and Forest Degradation in Developing Countries, Hanoi, Vietnam.

McKinley, C. 2007 Can a state owned media effectively monitor corruption? A study of Vietnam's printed press. Asian Journal of Public Affairs 2(1).

Meyfroidt, P. and Lambin, E.F. 2009 Forest transition in Vietnam and displacement of deforestation abroad. Proceedings of the National Academy of Sciences 106(38): 16139-16144.

Miller, M.M. and Riechert, B. 2000 Interest group strategies and journalistic norms: news media framing of environmental issues. In: Allan, S., Adam, B. and Carter, C. (eds) Environmental risks and the media, 45-54. Routledge, London.

Mormont, M. and Dasnoy, C. 1995 Source strategies and the communication of Media, Culture and Society 17:49-64.

Moser, S. and Dilling, L. (eds) 2007 Creating a climate for change: communicating climate change and facilitating social change. Cambridge University Press, Cambridge, UK.

Murdock, G., Petts, J. and Horlick-Jones, T., 2003 In: Pidgeon, N., Kasperson, R.E. and Slovic, P. (eds) The social amplification of risk, 159-174. Cambridge University Press, Cambridge.

Nguyen, T.H., Vu, T.H. and Pham, T.T. 2010 Vietnam REDD country profile. CIFOR, Bogor, Indonesia.

Nhan Dan 2010. About Nhan Dan. Available at: http://www. nhandan.org. vn/english/about.htm.

Oxfam 2009. Responding to climate change in Vietnam: opportunities for improving gender equality. Oxfam, Vietnam.

Painter, J. 2007 All doom and gloom? International TV coverage of the April and May 2007 IPCC reports. http://www.eci.ox.ac.uk/news/ events/070727-carbonundrum/painter.pdf (7 Feb. 2011).

Paletz, D.L. 1999 The media in American politics: contents and consequences. Longman, New York USA.

Pearman, C. 2010 Climate change in Asia: the impact on migrant workers and refugees-chapter 6 : Climate change and effects in Vietnam. http:// factfromfiction.wordpress.com/2010/09/07/ climate-change-in-asia-the-impact-on-migrant- 
workers-and-refugees- $\%$ E2\%80\%93-chapter-6climate-change-and-effects-in-vietnam/ (7 Feb. 2011).

Pham, M.C. 2009 Vietnam experience on REDD. Prospects_Challenges_REDD -PhamManhCuong.pdf, available at www.gmseoc.org. (10 February 2011).

Pham, T.T., Campbell, B.M. and Garnett, S. 2009 Lessons learnt and pitfalls of PES projects in Vietnam. Asian Pacific Journal of Public Administration 31(2): 117-135.

Pham, T.T., Campbell, B.M., Garnett, S., Aslin, H. and Hoang, M.H. 2010. Importance and impacts of intermediary boundary organisations in facilitating payment for environmental services in Vietnam. Environmental Conservation, 37(1): 64-72.

Pham, T.T., Hoang, M.H. and Campbell, M.B. 2008 Pro-poor payments for environmental services: challenges for the government and administrative agencies in Vietnam. Public Administration and Development 28(5): 363-373.

Politics and perceptions of risk. In: Allan, S., Adam, B. and Carter, C. (eds) Environmental risks and the media, 201-217. Routledge, London.

Rogers, E.M. and Dearing, J.W. 2007 Agenda-setting research: where has it been, where is it going? In: Graber, D.A. (ed.) Media power in politics, 8097. CQ Press, Washington, DC.

Schoenfeld, A.C., Meier, R.F. and Griyn, R.J. 1979 Constructing a social problem: the press and the environment. Social Problems 27(1): 38-61.

Shanahan, M. 2007 Talking about a revolution: climate change and the media. An IIED Briefing. International Institute for Environment and Development, London.

Spector, M. and Kitsuse, J. 1977 Constructing social problems. Cummings, Menlo Park, USA.

Tran, D.T.L. 2005 Media seen as watchdogs but get bitten. psnews.net/news.asp?idnews=30009.
Tuoi Tre 2010 About us. Available at: tuoitre.vn/ (10 February 2011).

Tuula, T. 2010 Political opportunities and storylines in Finnish climate policy negotiations. Environmental Politics 19(2): 196-216.

Tynkkynen, N. 2010 A great ecological power in global climate policy? Framing climate change as a policy problem in Russian public discussion. Environmental Politics 19(2): 179-195.

Van Noordwijk, M., Leimona, B., Emerton, L., Tomich, P.T., Velarde, J.S., Kallesoe, M., Sekher, M. and Swallow, B. 2007 Criteria and indicators for environmental service compensation and reward mechanisms: realistic, voluntary, conditional and pro-poor. CES Scoping Study Issue Paper no. 2. ICRAF Working Paper no. 37. World Agroforestry Centre, Nairobi, Kenya.

Videa, P.B. 2010 Media analysis Bolivia. CIFOR, Bogor, Indonesia.

Villamor, G., van Noordwijk, M., Agra, F. and Catacutan, D. 2007 Buyers' perspectives on environmental services (ES) and commoditization as an approach to liberate ES markets in the Philippines. Working Paper no. 51. World Agroforestry Centre, Nairobi, Kenya.

Wertz-Kanounnikoff, S. and Rankine, H. 2008 How can governments promote strategic approaches to payments for environmental services (PES)? An exploratory analysis for the case of Vietnam. IDDRI Analyses No. 3/2008. Institut du développement durable et des relations internationales, Paris.

Wilson, K.M. 1995 Mass media as sources of global warming knowledge. Mass Communication Review 22: 75-89.

Wilson, K.M. 2000. Communicating climate change through the media: predictions, politics, and perceptions of risks. In Allan S, Adam B, Carter C (eds) Environmental Risks and the Media, 201217. Routledge, New York. 


Since 2009, CIFOR has initiated the Global Comparative Study of REDD+ in six countries: Bolivia, Brazil, Cameroon, Indonesia, Tanzania and Vietnam. In analysing national REDD+ policy arenas and emerging strategies, CIFOR researchers have developed five areas of work for each country. These include a country profile, media analysis, policy network analysis, strategy assessment and a fifth area of specific policy studies, to be determined by emerging research results. In 2010 we are publishing the first country profiles and media analyses.

\section{的} NORWEGIAN MINISTRY OF THE ENVIRONMENT NORWEGIAN MINISTRY OF FOREIGN AFFAIRS RY

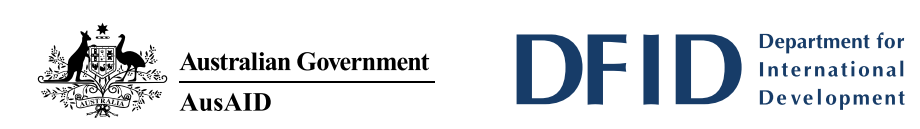

International
Development

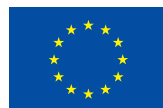

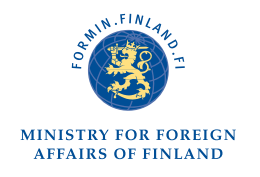

the David E
Lucile Packard
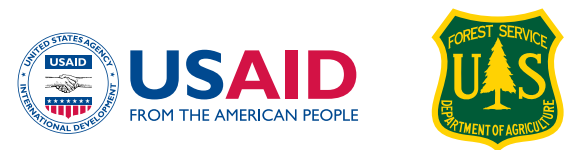

Center for International Forestry Research

CIFOR advances human wellbeing, environmental conservation and equity by conducting research to inform policies and practices that affect forests in developing countries. CIFOR is one of 15 centres within the Consultative Group on International Agricultural Research (CGIAR). CIFOR's headquarters are in Bogor, Indonesia. It also has offices in Asia, Africa and South America. 